Elsevier required licence: (c) $<2018>$. This manuscript version is made available under the CC-BY-NC-ND 4.0 license http://creativecommons.org/licenses/bync-nd/4.0/ 

9 0

\title{
Development of ultra-high performance concrete with high fire resistance
}

\author{
Xiangwei Liang ${ }^{\mathrm{a}, *}$, Chengqing $\mathrm{Wu}^{\mathrm{a}}$, $\mathrm{Yu} \mathrm{Su}{ }^{\mathrm{a}}$, Zhu Chen ${ }^{\mathrm{b}}$, Zhongxian $\mathrm{Li}^{\mathrm{b}}$ \\ ${ }^{a}$ Centre for Built Infrastructure Research, School of Civil and Environmental \\ Engineering, University of Technology Sydney, NSW 2007, Australia \\ ${ }^{\mathrm{b}}$ Tianjin Key Laboratory of Civil Structure Protection and Reinforcement, Tianjin \\ Chengjian University, Tianjin 300384, China
}

\section{Abstract} 2

Fire or high temperature is a big challenge to ultra-high performance concrete (UHPC). Strength loss of UHPCs can reach up to $80 \%$ after exposure to $800{ }^{\circ} \mathrm{C}$. In this study, a total of six UHPC mixtures were designed and tested after subjected to elevated temperatures up to $1000{ }^{\circ} \mathrm{C}$. The effects of aggregate type, fibre type and heating rate were investigated. Residual compressive strengths and stress-strain relationships were studied. Besides, attention was paid to explosive spalling since UHPCs are usually of compact structure and thus more vulnerable to explosive spalling than other concretes. 0 Scanning electron microscope (SEM) analysis was conducted to help understand the 1 mechanism of variation of internal structure under different temperatures. It was found 2 the mixture containing steel slag and hybrid fibre had excellent fire resistance. After 3 being subjected to $1000{ }^{\circ} \mathrm{C}$, this mixture retained a residual compressive strength of $4112.8 \mathrm{MPa}$ or a relative value of $69 \%$.

\section{5}

6 Keywords: Ultra-high performance concrete; Fire resistance; Steel slag; Steel fibre; 7 Polypropylene fibre; Elevated temperature 28

\footnotetext{
* Corresponding author.

E-mail addresses: xiangwei.liang@student.uts.edu.au (X. Liang), chengqing.wu@uts.edu.au (C. $\mathrm{Wu})$.
} 


\section{Introduction}

34 Due to rampant terrorism, governments and researchers are paying growing attention to protective structures against blast and fire. UHPC is considered a desirable material for this kind of structures. The Portland Cement Association (PCA) defines UHPC as "a high-strength, ductile material formulated by combining portland cement, silica fume, quartz flour, fine silica sand, high-range water reducer, water, and steel or organic fibers. The material provides compressive strengths up to 29,000 pounds per square inch (psi) and flexural strengths up to 7,000 psi". By contrast, normal strength concrete (NSC) and high performance concrete (HPC) are much inferior in performance such as strength, toughness, ductility and durability. In the last decades, a lot of effort has been made to improve mechanical properties of UHPC. For example, most recently some nano materials were investigated as a new additive to UHPCs $[1,2]$. However, fire or high temperature is still a great threat to all kinds of concretes including UHPCs.

Chan et al. [3] experimentally studied the behaviour of HPC subjected to high temperatures up to $800{ }^{\circ} \mathrm{C}$ and they found the compressive strength of HPCs degraded more sharply than NSCs. Similar findings were obtained by [4, 5]. Sobia et al. [6] carried out a comparative study on ultra-high performance fibre-reinforced

51 cementitious composites (UHPFRCC) before and after heat treatment. Their test 52 results revealed the residual compressive strength of UHPFRCC after being exposed 53 to $1,000{ }^{\circ} \mathrm{C}$ was around $41 \%$ of its room-temperature strength. Much severer 54 deterioration was observed by $[4,7,8]$. Choe et al. [4] suggested the relative residual 55 compressive strength of ultra-high-strength concrete being heated to $1,000{ }^{\circ} \mathrm{C}$ was 
only $2 \%$. Another threat a fire can pose to UHPCs is explosive spalling and severe explosive spallings were observed by Kahanji et al. [9, 10]. Lin et al. [11] and Akca and Zihnioğlu [12] proposed that increasing pore pressure due to water evaporating and thermal strain were the major reasons for concrete spalling. UHPCs usually suffer more serious spalling than NSCs due to their compact structure and low porosity. Therefore, it is of high significance to develop UHPCs that have better fire resistance.

Industrial by-products, such as slag and silica fume, have been widely investigated by researchers as replacement of constituents of concrete to achieve environmental benefit as well as better concrete performance. Steel slag is produced under a high temperature of $1,650{ }^{\circ} \mathrm{C}$ so that organic, semi-volatile and volatile compounds are removed. Mainly steel slag consists of calcium silicates, ferrites oxides and compounds of iron, magnesium, manganese and alumina. The physical and chemical analyses showed steel slag aggregate is tough, durable, and of relatively high porosity and density [13]. Guo et al. [14] conducted an experimental study to investigate effect of steel slag powder on workability and durability of concrete. They found compared to addition of ground granulated blast furnace slag (GGBFS) alone to concrete, combined admixture of GGBFS and steel slag could achieve lower dry shrinkage and better abrasion resistance. Especially, when activators such as desulphurization, residue sodium sulfate and desulphurization gypsum were integrated, steel slag significantly improved resistance of the concrete to chloride permeation and water permeation and carbonisation depth. Netinger et al. [15] studied steel slag as a coarse aggregate in concrete and concluded steel slag could be an acceptable aggregate of concrete for structural use and posed no risk in terms of corrosion of reinforcement. Qasrawi et al. [16] investigated the effect of steel slag at different replacement ratios 
81 of fine aggregate. They proposed use of steel slag in concrete could greatly enhance strength of concrete, especially tensile strength, if appropriate ratio of steel slag to cement was used. Effect of high temperatures on concrete with inclusion of slag has also been studied by several researchers. Yüksel et al. [17] observed that the residual compressive strength of specimens containing blast-furnace slag or coal bottom ash was lower than the reference concrete that did not contain any slag or coal bottom ash. Netinger et al. [18] suggested steel slag as coarse aggregate could improve fire resistance of concrete only if it was combined with a binder that was able to better adapt to slag expansion under high temperature or used as a partial replacement for coarse aggregate. Silica fume is an ultra-fine reactive powder and inclusion of it can

91 improve properties of concrete particularly in compressive strength, bond strength and abrasion resistance due to pozzolanic reactions between silica fume and free calcium hydroxide $(\mathrm{CH})$ in the cement paste [19].

To date, some efforts have been made to investigate influence of incorporation of slag into UHPCs $[20,21]$ or other types of concretes [18, 22-24]. However, there are currently very limited researches with respect to the effect of slag on the performance of UHPCs subjected to high temperatures. As discussed above, UHPCs could experience severe explosive spalling and suffer dramatic strength loss after being

100 exposed to elevated temperatures. On the other hand, steel slag, as a potential

101 desirable aggregate of refractory concrete, is still dumped as a land-fill material in a 102 significant amount today [13]. This study is to develop a UHPC with high fire 103 resistance. To improve fire resistance of concrete, steel fibre and polypropylene (PP) 104 fibre are usually incorporated into concrete mixtures [2, 3, 12, 25, 26]. PP fibre is 105 broadly considered beneficial to control explosive spalling since it melts at around 
$106160{ }^{\circ} \mathrm{C}$, leaving a network of escaping channels for vapour and thus helping reduce

107 internal vapour pressure [12, 27-30]. However, so far fire resistance of UHPCs

108 remains a problem of concern even though hybrid fibre is used. In the literature,

109 residual compressive strengths of UHPCs are less than $40 \%$ of their room-temperature

110 strength after being exposed to high temperatures below $1000{ }^{\circ} \mathrm{C}[7,8,25]$. In this

111 study, by using steel slag as fine aggregate and incorporating other industrial

112 by-products and hybrid fibres, a UHPC with $69 \%$ relative residual strength after

113 subjected to $1000^{\circ} \mathrm{C}$ has been successfully developed.

\section{2. Experimental details}

\subsection{Materials}

119 The cement used in all mixtures in this study was ordinary Portland cement (42.5

120 Grade). The silica fume added to the mixtures had a bulk weight of $200-250 \mathrm{~kg} / \mathrm{m}^{3}$, a

121 specific surface area of $20-28 \mathrm{~m}^{2} / \mathrm{g}$, and a particle diameter of $0.1-0.3 \mu \mathrm{m}$. Like

122 silica fume, fly ash is a reactive material and has pozzolanic effect in the concrete 123 mixture which helps convert free $\mathrm{CH}$ into calcium silicate hydrate $(\mathrm{C}-\mathrm{S}-\mathrm{H})$ gel, so it

124 was also applied to all specimens. The fly ash had a standard spherical shape, a

125 density of $2.5 \times 10^{3} \mathrm{~kg} / \mathrm{m}^{3}$, a stacking density of $0.7 \times 10^{3} \mathrm{~kg} / \mathrm{m}^{3}$ and a thixotropic

126 index of 8 . Sieve analysis was conducted on the two types of fine aggregate, i.e.

127 quartz sand and steel slag, as shown in Fig. 1. The chemical compositions of cement,

128 silica fume, fly ash and steel slag are listed in Table 1. The quartz sand has a density

129 of $2.65 \times 10^{3} \mathrm{~kg} / \mathrm{m}^{3}$, a hardness of 7 and a melting point of $1,650{ }^{\circ} \mathrm{C}$. It needs to be

130 noted no coarse aggregate was used in any specimens, which avoided expansion 
131 incompatibility between coarse aggregate and surrounding cement paste under 132 elevated temperatures.

133

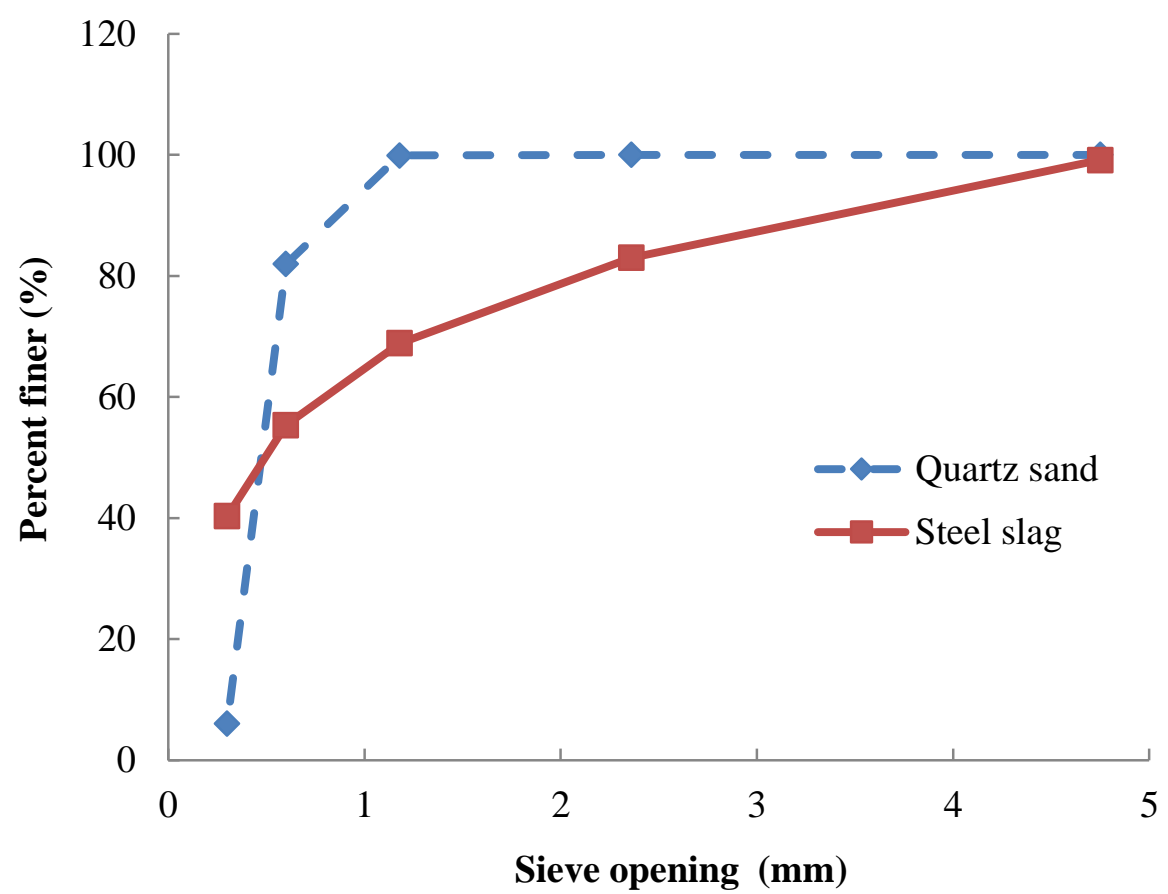

Sieve opening $(\mathbf{m m})$

Fig. 1. Sieve analysis of quartz sand and steel slag

137 Table 1

138 Chemical compositions of cement, silica fume, fly ash and steel slag (\%)

\begin{tabular}{lllllll}
\hline Materials & $\mathrm{SiO}_{2}$ & $\mathrm{Al}_{2} \mathrm{O}_{3}$ & $\mathrm{Fe}_{2} \mathrm{O}_{3}$ & $\mathrm{CaO}$ & $\mathrm{MgO}$ & Loss of ignition \\
\hline Cement & 21.86 & 4.25 & 2.66 & 63.59 & 2.19 & 1.75 \\
Silica fume & 93.95 & 0.5 & 0.59 & 1.95 & 0.27 & 1.3 \\
Fly ash & 52 & 22 & 4 & 12 & 0.62 & $<1$ \\
Steel slag & 17.03 & 5.64 & 22.69 & 43.38 & 5.98 & 1.56 \\
\hline
\end{tabular}

139

140 Two types of fibre, i.e. steel fibre and PP fibre, were either or both incorporated into

141 the UHPC mixtures (see Fig. 2). The steel fibre had a round straight shape and the 
142 properties of steel fibre and PP fibre are reported in Table 2.

143

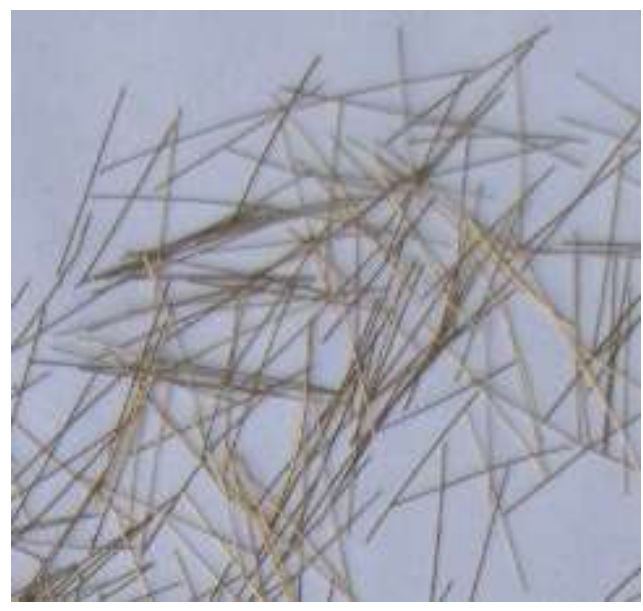

(a) Steel fibre

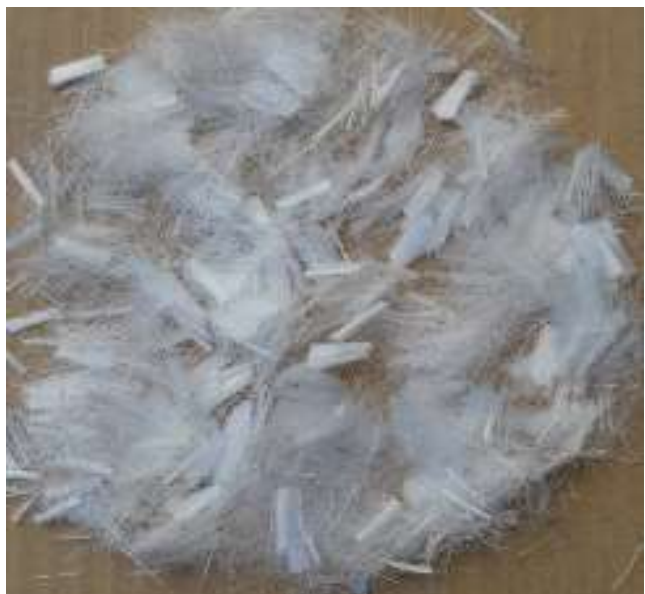

(b) PP fibre

Fig. 2. Steel fibre and PP fibre.

145

146 Table 2

147 Properties of steel fibre and PP fibre

\begin{tabular}{|c|c|c|c|c|c|c|}
\hline & $\begin{array}{l}\text { Length } \\
(\mathrm{mm})\end{array}$ & $\begin{array}{l}\text { Diameter } \\
(\mathrm{mm})\end{array}$ & $\begin{array}{l}\text { Density } \\
\left(\mathrm{g} / \mathrm{cm}^{3}\right)\end{array}$ & $\begin{array}{l}\text { Modulus of } \\
\text { elasticity } \\
(\mathrm{GPa})\end{array}$ & $\begin{array}{l}\text { Tensile } \\
\text { strength } \\
(\mathrm{MPa})\end{array}$ & $\begin{array}{l}\text { Melting } \\
\text { point }\left({ }^{\circ} \mathrm{C}\right)\end{array}$ \\
\hline Steel fibre & 10 & 0.12 & 7.8 & - & $>2500$ & - \\
\hline PP fibre & 10 & 0.0031 & 0.91 & $\geq 3.5$ & $\geq 400$ & 165 \\
\hline
\end{tabular}

148

\subsection{Mixture proportioning}

150

151 Totally six mixtures were prepared and they were divided into two series according to

152 different fine aggregates, i.e. quartz sand or steel slag, with details shown in Table 3.

153 The series 1 used quartz sand as fine aggregate, while the series 2 used steel slag. 
154 Mixtures in series 1 were divided into four categories according to fibre inclusion, i.e.

155 no fibre, 2 vol.\% steel fibre, 2 vol.\% PP fibre or combination of 1 vol.\% steel fibre

156 and 2 vol.\% PP fibre. Mixtures in series 2 were divided into two categories according

157 to fibre inclusion, i.e. no fibre or combination of 1 vol.\% steel fibre and 2 vol.\% PP

158 fibre. For designation of the six mixtures, the letter before the hyphen denotes the type

159 of fine aggregates, i.e. Q for quartz sand and $\mathrm{S}$ for steel slag, while the letter behind the

160 hyphen means the type of fibres, i.e. 0 for no fibre, $\mathrm{S}$ for steel fibre, $\mathrm{P}$ for PP fibre and

161 SP for hybrid fibre. Water to binder ratio was set at 0.16 and sand to binder ratio at 1.0

162 for all the mixtures. Unit weight for all the mixtures and slump for the mixtures Q-SP,

163 S-0 and S-SP are listed in Table 4. The slump tests were conducted conforming to the

164 Chinese standard GB/T 50080-2016. It can be seen the slump of the Q-SP and S-SP

165 concretes was greatly reduced by inclusion of the hybrid fibre.

166

167 Table 3

168 Mixture proportions of UHPCs (unit: $\mathrm{kg} / \mathrm{m}^{3}$ )

\begin{tabular}{|c|c|c|c|c|c|c|}
\hline \multirow{2}{*}{ Constituents } & \multicolumn{4}{|c|}{ Series 1} & \multicolumn{2}{|c|}{ Series 2} \\
\hline & Q-0 & Q-S & Q-P & Q-SP & $\overline{S-0}$ & S-SP \\
\hline 42.5 cement & 850 & 850 & 850 & 850 & 850 & 850 \\
\hline Silica fume & 137.5 & 137.5 & 137.5 & 137.5 & 137.5 & 137.5 \\
\hline Fly ash & 112.5 & 112.5 & 112.5 & 112.5 & 112.5 & 112.5 \\
\hline Water & 176 & 176 & 176 & 176 & 176 & 176 \\
\hline Superplasticizer & 8 & 8 & 8 & 8 & 8 & 8 \\
\hline Quartz sand & 1,100 & 1,100 & 1,100 & 1,100 & - & - \\
\hline Steel slag & - & - & - & - & 1,100 & 1,100 \\
\hline
\end{tabular}


Steel fibre

PP fibre

Table 4

171 Unit weight and slump of UHPC mixtures

\begin{tabular}{lllllll}
\hline & Q-0 & Q-S & Q-P & Q-SP & S-0 & S-SP \\
\hline Unit weight & 2,450 & 2,610 & 2,250 & 2,460 & 2,590 & 2,700 \\
$\left(\mathrm{~kg} / \mathrm{m}^{3}\right)$ & & & & & & \\
Slump (mm) & - & - & - & 70 & 295 & 75 \\
\hline
\end{tabular}

\subsection{Specimen preparation and tests}

The compression tests were carried out for five target temperatures, i.e. 200, 400, 600,

176800 and $1,000{ }^{\circ} \mathrm{C}$. Under each target temperature, four specimens were prepared and

177 tested allowing for randomness of explosive spalling. There were totally 144 specimens

178 and all specimens had a cubic shape. A side length of $50 \mathrm{~mm}$ rather than larger was

179 chosen for all the specimens in order to avoid too frequent occurrence of explosive

180 spalling. To prepare the specimens, a forced mixer with $30 \mathrm{~L}$ capacity was used. Firstly,

181 the fine aggregate was fed into the mixer and mixed with a small amount of water for

182 two minutes. Then cement, silica fume and fly ash were added and mixed for five

183 minutes before water and superplasticizer were poured. The mixing process continued

184 for another eight minutes. Finally, fibres were added to the mixture and mixed for five

185 more minutes before the mixture was cast in the steel moulds. 24 hours later, the

186 specimens were demoulded and put into a water tank with thermostatic control, where 187 they were submerged by hot water of constant $90{ }^{\circ} \mathrm{C}$ for one day in order to accelerate 
pozzolanic reaction. Then, they were cured under a standard curing condition for 28

189 days. Before heating, a drying treatment is usually needed to control explosive

190 spalling. Okpala [31] used a mechanically ventilated oven to dry the paste and mortar

191 specimens at $105 \pm 1{ }^{\circ} \mathrm{C}$ for a duration of 5-6 days. However, after a comparative

192 study of different drying temperatures and facilities, Gallé [32] suggested $105^{\circ} \mathrm{C}$ could

193 be too high to prevent microstructure of the specimen from being impacted by oven

194 drying treatment. In this study, the specimens were put into an electric furnace for a

195 drying treatment under a temperature of $90{ }^{\circ} \mathrm{C}$ for 24 hours, which proved to be an

196 effective means to control explosive spalling. Since all the six UHPC mixtures were

197 prepared with the identical water content, i.e. $176 \mathrm{~kg} / \mathrm{m}^{3}$, and experienced the same

198 procedure of curing and drying, it was supposed they had the similar initial moisture

199 level.

201 The specimens were heated in an electric furnace with a heating capability of $1400^{\circ} \mathrm{C}$.

202 Real fire condition could be simulated as per the heating curve defined in the standards

203 ISO 834 [33] which has an exponential relationship between growing temperature and

204 heating time. However, to make the heating process simple, some researchers such as 205 [34] applied a constant heating rate of $5{ }^{\circ} \mathrm{C} / \mathrm{min}$ according to the standards ASTM E831

206 [35]. In this study, $4{ }^{\circ} \mathrm{C} / \mathrm{min}$ was selected as the heating rate according to ASTM E831

207 [35] and 1 and $8^{\circ} \mathrm{C} / \mathrm{min}$ heating rates were chosen to make a comparison study in 208 subsection 3.2.1. Compact concrete like UHPC is vulnerable to explosive spalling 209 when being heated. To prevent damage to the furnace and ensure safety, silicon boards 210 were mounted on the chamber inner walls of the furnace. Furthermore, a steel cage 211 was presented inside the furnace to contain specimens being heated. At a time, four 212 specimens were heated at a rate of $4{ }^{\circ} \mathrm{C} / \mathrm{min}$ until reaching the target temperatures and 
213 then they remained subjected to the constant target temperatures for another period of

214 time or called holding time to achieve uniformly distributed temperatures throughout

215 the specimen. The holding time, according to Chen et al. [36], has a significant impact

216 on stress-strain behaviour of concretes exposed to high temperatures. To determine an

217 appropriate holding time, a heating simulation with target temperature $1000{ }^{\circ} \mathrm{C}$ was

218 conducted using the thermal parameters from the European standard [37]. Fig. 3

219 shows the temperature time-history in the furnace chamber and at the centre of the

220 model. It can be seen after 2 hours holding time (from 245 to $365 \mathrm{~min}$ ), the

221 temperature at the specimen centre is $999.3{ }^{\circ} \mathrm{C}$, very close to the target temperature.

222 For target temperatures lower than $1000{ }^{\circ} \mathrm{C}$, the temperature gap between the furnace

223 chamber and the centre of the model is smaller, as shown in Fig. 3. Because concrete

224 has higher thermal conductivity and lower specific heat under lower temperatures, it is

225 no doubt the valid holding time for higher target temperature ensures uniform

226 temperature distribution in case of lower target temperatures. Hence, in this study the

227 holding time for all specimens was consistently set at 2 hours to ensure uniformly

228 distributed temperatures, at the same time to avoid impact of this factor. Afterwards,

229 the furnace door was opened to let the specimens cool down to room temperature. It

230 should be noted in this study temperatures were measured by the thermocouple

231 mounted on the internal wall of the furnace unless specified otherwise. 


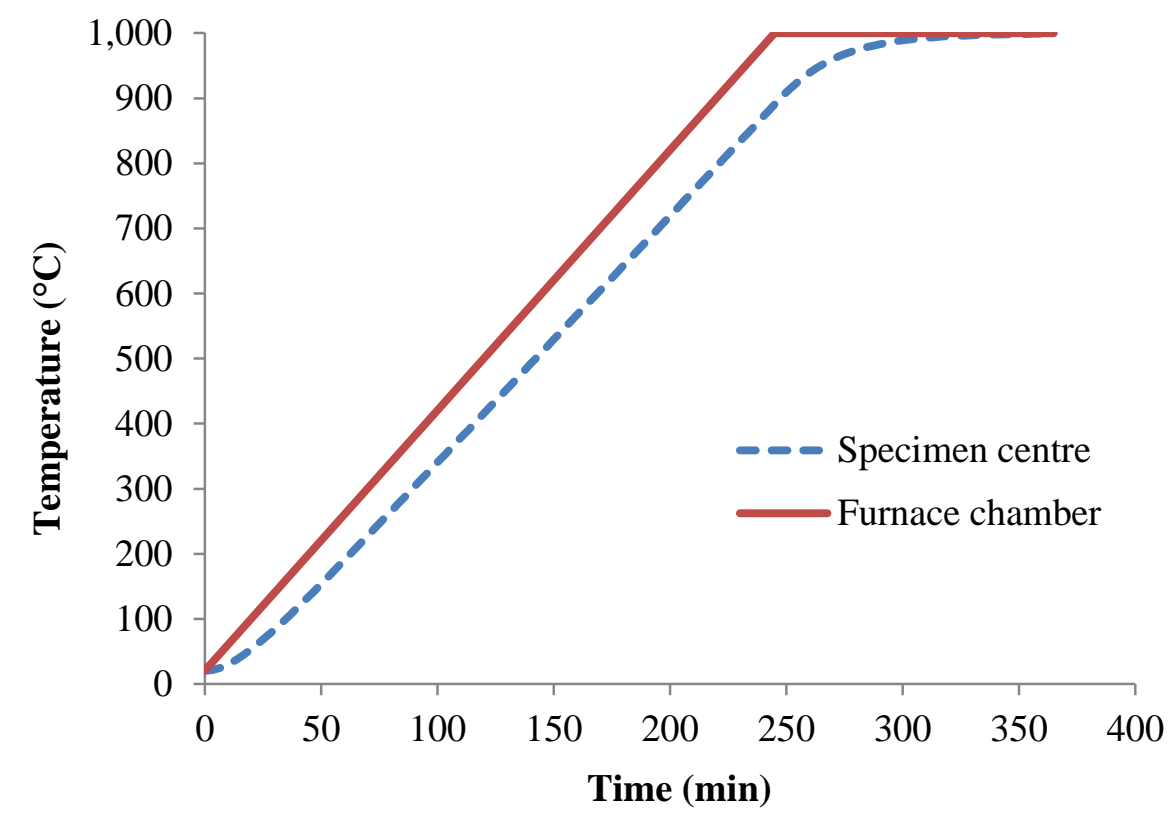

234 Fig. 3. Comparison of temperature time-history between furnace chamber and specimen centre under target temperature $1000^{\circ} \mathrm{C}$

237 Compressive tests were implemented on a $1,000 \mathrm{kN}$ capacity electrohydraulic servo 238 pressure testing machine, with the procedure conforming to the Chinese standard 239 JGJ70-2009. The loading rate was controlled at $0.2 \mathrm{~mm} / \mathrm{min}$ and the loading and 240 displacement data were recorded automatically. To measure the displacement, two 241 displacement gauges were symmetrically mounted on the two sides of the specimen 242 between the loading plates, as illustrated in Fig. 4. In this study, the compressive 243 strength was calculated as the average value of four specimens. Results for all mixtures 244 are reported in Table 5, where $f_{c}$ denotes compressive strength of the specimens which 245 were not exposed to high temperatures (i.e. control specimens), $f_{c T}$ denotes 246 compressive strength of the specimens which were exposed to high temperatures and $247 f_{c T} / f_{c}$ means normalised compressive strength. It should be noted while most of the test 248 results were an average of four specimens, some came from three due to explosive 249 spalling. Due to severe explosion, data for the mixtures Q-0, Q-S and S-0 were not 


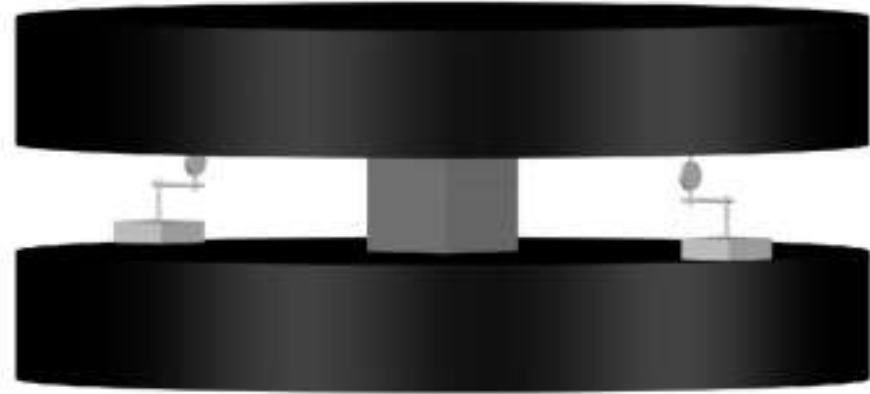

255 Table 5

256 Compressive strength under various temperatures

\begin{tabular}{|c|c|c|c|c|c|c|c|}
\hline Tempera- & & Q-0 & Q-S & Q-P & Q-SP & S-0 & S-SP \\
\hline ture $\left({ }^{\circ} \mathrm{C}\right)$ & & & & & & & \\
\hline 20 & $f_{c}(\mathrm{MPa})$ & 112.4 & 187.5 & 125.5 & 162.1 & 90.0 & 162.8 \\
\hline 200 & $f_{c T}(\mathrm{MPa})$ & 164.7 & 204.8 & 132.5 & 176.2 & 191.0 & 182.5 \\
\hline & $f_{c T} / f_{c}$ & 1.47 & 1.09 & 1.06 & 1.09 & 2.12 & 1.12 \\
\hline 400 & $f_{c T}(\mathrm{MPa})$ & - & - & 163.5 & 230.1 & - & 215.9 \\
\hline & $f_{c T} / f_{c}$ & - & - & 1.30 & 1.42 & - & 1.33 \\
\hline 600 & $f_{c T}(\mathrm{MPa})$ & & - & 112.3 & 153.8 & - & 208.3 \\
\hline & $f_{c T} / f_{c}$ & - & - & 0.89 & 0.95 & - & 1.28 \\
\hline 800 & $f_{c T}(\mathrm{MPa})$ & - & - & 38.1 & 40.0 & - & 147.6 \\
\hline & $f_{c T} / f_{c}$ & - & - & 0.30 & 0.25 & - & 0.91 \\
\hline 1,000 & $f_{c T}(\mathrm{MPa})$ & & - & 37.5 & 40.4 & - & 112.8 \\
\hline
\end{tabular}




$\begin{array}{lllllll}f_{c T} f_{c} & - & - & 0.30 & 0.25 & - & 0.69\end{array}$

\section{Results and discussion}

\subsection{Mass loss}

In this paper, mass loss refers to water evaporation and gas escape from UHPCs being

263 heated. The relationship between mass loss and temperature for all the mixtures is 264 depicted in Fig. 5. It can be seen all mixtures had a small mass loss below $200{ }^{\circ} \mathrm{C}$, 265 indicating the UHPC specimens had a very compact structure which hindered vapour 266 from escaping. For mixtures without PP fibres, i.e. the Q-0, Q-S and S-0 concretes, data 267 were not recorded above $200{ }^{\circ} \mathrm{C}$ due to the severe explosion. Being heated to $200{ }^{\circ} \mathrm{C}$, 268 both the Q-0 and the Q-S specimens experienced an average mass loss of $1 \mathrm{~g}$ or $0.34 \%$ 269 in percentage, indicating steel fibre had little influence in mass loss of UHPCs 270 exposed to elevated temperatures below $200{ }^{\circ} \mathrm{C}$. The mass loss of the other three 271 mixtures containing PP fibres increased sharply between $200{ }^{\circ} \mathrm{C}$ and $400{ }^{\circ} \mathrm{C}$. It was 272 because the PP fibres melting at $165^{\circ} \mathrm{C}$ provided a network of escaping channels for 273 the vapour, while a majority of vapour came from the capillary water and bound water 274 between $200{ }^{\circ} \mathrm{C}$ and $400{ }^{\circ} \mathrm{C}$. Research conducted by Tsuchiya and Sumi [38] revealed 275 between temperature range of 360 to $400{ }^{\circ} \mathrm{C}$ PP could decompose into various 276 volatiles such as Pentane and Propylene, which was another contribution of the mass 277 loss. Then with temperature growing from $400{ }^{\circ} \mathrm{C}$ to $1,000{ }^{\circ} \mathrm{C}$, the mass loss rose 278 slightly and peaked at around 8\%. It can be seen from Fig. 5 that the mass loss of the 279 Q-P mixture was a little higher than the Q-SP and the S-SP mixtures. The reason 280 could be the Q-P concrete didn't contain steel fibres and thus suffered severer cracking 
281 and spalling, which boosted the escaping of vapour and smoke. Another possible 282 reason could be the Q-P concrete as an exception might have more moisture or higher 283 pore volume. The S-SP concrete suffered the smallest mass loss among the three 284 mixtures containing PP fibres, indicating this mixture had more compact structure 285 than the Q-SP concrete, which agreed with the fact that the latter had a lower 286 probability of occurrence of explosive spalling than the former. From $800{ }^{\circ} \mathrm{C}$ to $2871,000{ }^{\circ} \mathrm{C}$, the mass loss of Q-SP and S-SP concretes decreased because they took in 288 moisture from the air during a one-day cooling.

289

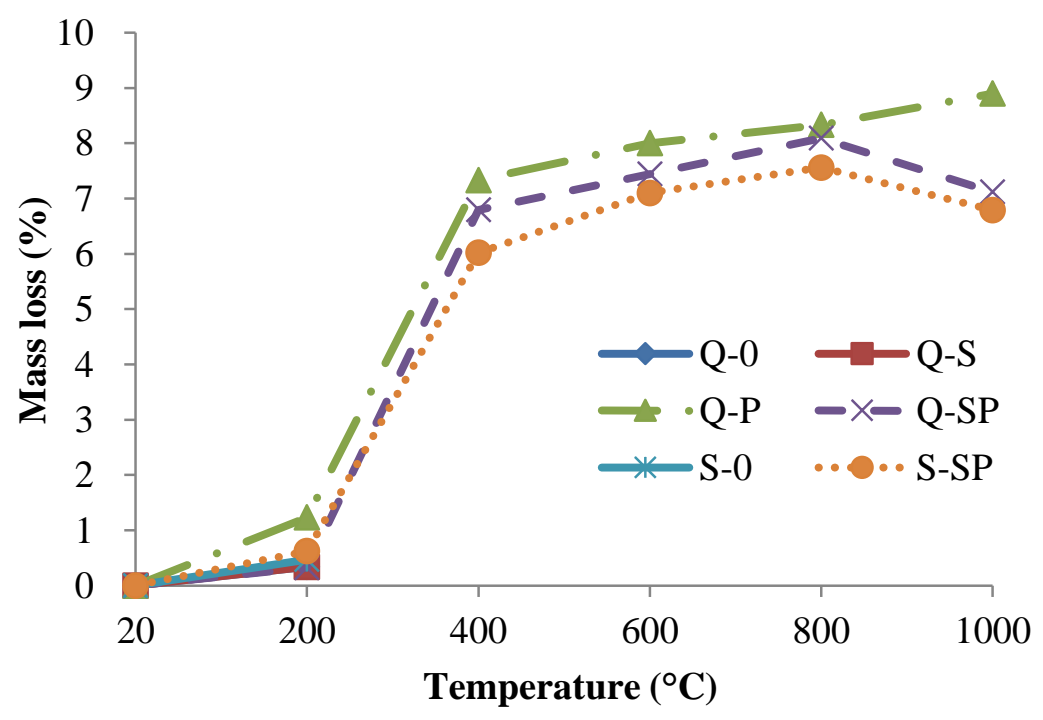

Fig. 5. Mass loss under different temperatures.

297 To investigate the effect of heating rate on explosive spalling of heated UHPCs, three 298 heating rates, i.e. 1,4 and $8{ }^{\circ} \mathrm{C} / \mathrm{min}$, were applied to the Q-S concrete. The target 
temperature under 1 and $4{ }^{\circ} \mathrm{C} / \mathrm{min}$ heating rates was set at $400{ }^{\circ} \mathrm{C}$, while under $8^{\circ} \mathrm{C} / \mathrm{min}$ was set at $600{ }^{\circ} \mathrm{C}$.

302 The spalling details of the Q-S concrete are reported in Table 6. It was observed under

303 whatever heating rates all the specimens suffered serious explosive spalling, which

304 suggested the heating rate had nothing to do with the probability of explosive spalling 305 in the case of Q-S concrete that was very dense and without PP fibres. However, with 306 the increase of heating rate, the explosive spalling started and ended earlier, both the 307 spalling starting temperature and the spalling ending temperature became higher, and 308 the smoke escaping temperature range became on a higher level. During the heating, 309 there were several intense explosions happening under whatever heating rates, with big 310 burst sounds being heard. Each intense explosion came with the escape of a large 311 amount of vapour and dust, which could be observed outside the furnace. This 312 phenomenon indicated that the accumulation of internal vapour pressure was a big 313 contribution of the explosive spalling.

315 Table 6

316 Details of explosive spalling of Q-S concrete at different heating rates

\begin{tabular}{lccc}
\hline Heating rate $\left({ }^{\circ} \mathrm{C} / \mathrm{min}\right)$ & 1 & 4 & 8 \\
\hline Target temperature $\left({ }^{\circ} \mathrm{C}\right)$ & 400 & 400 & 600 \\
Probability $(\%)$ & 100 & 100 & 100 \\
Starting time $(\mathrm{min})^{\mathrm{a}}$ & 325 & 92 & 35 \\
Ending time $(\mathrm{min})^{\mathrm{a}}$ & 460 & 113 & 67 \\
Starting temperature $\left({ }^{\circ} \mathrm{C}\right)^{\mathrm{b}}$ & 323 & 357 & 422 \\
Ending temperature $\left({ }^{\circ} \mathrm{C}\right)^{\mathrm{b}}$ & 400 & 400 & 563
\end{tabular}


Smoke escaping temperature

range $\left({ }^{\circ} \mathrm{C}\right)^{\mathrm{c}}$

$\overline{\text { a Starting time is the time when spalling was first observed, while ending time is the }}$

318 time after which spalling would no longer occur.

319 b Starting temperature is the temperature at which spalling was first observed, while

320 ending temperature is the temperature above which spalling would no longer occur.

$321{ }^{\mathrm{c}}$ Smoke escaping temperature is the temperature range only within which smoke was

322 observed.

324 Table 7 shows the explosive spalling of the Q-S specimens heated under the three 325 heating rates. It can be seen with higher heating rate and higher target temperature the 326 debris of the specimens tended to be smaller, indicating more intense explosive 327 spalling.

329 Table 7

330 Explosive spalling of Q-S concrete at different heating rates

Heating rate

$\left({ }^{\circ} \mathrm{C} / \mathrm{min}\right)$

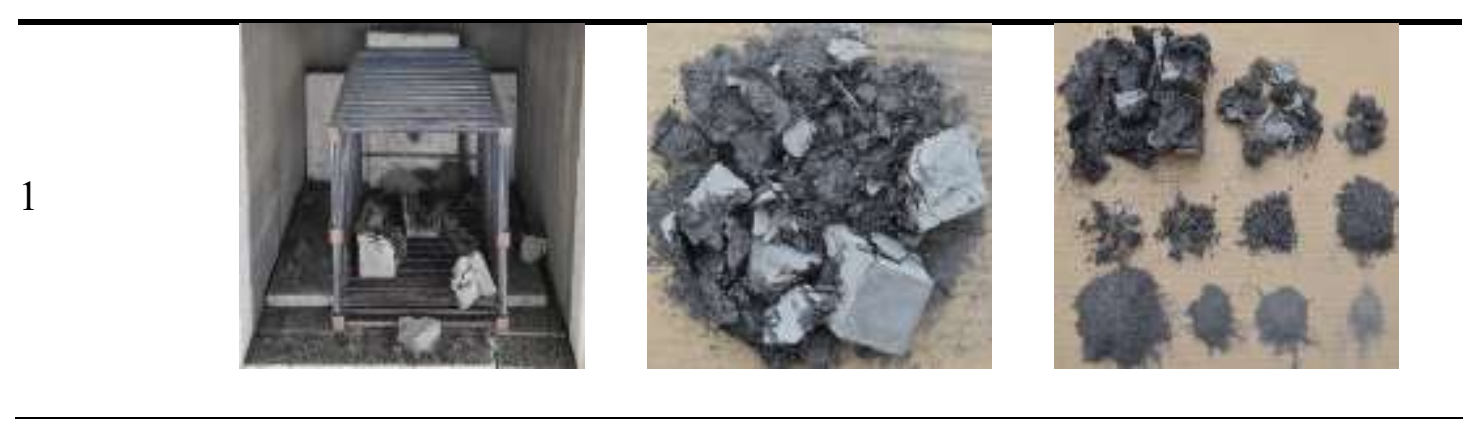




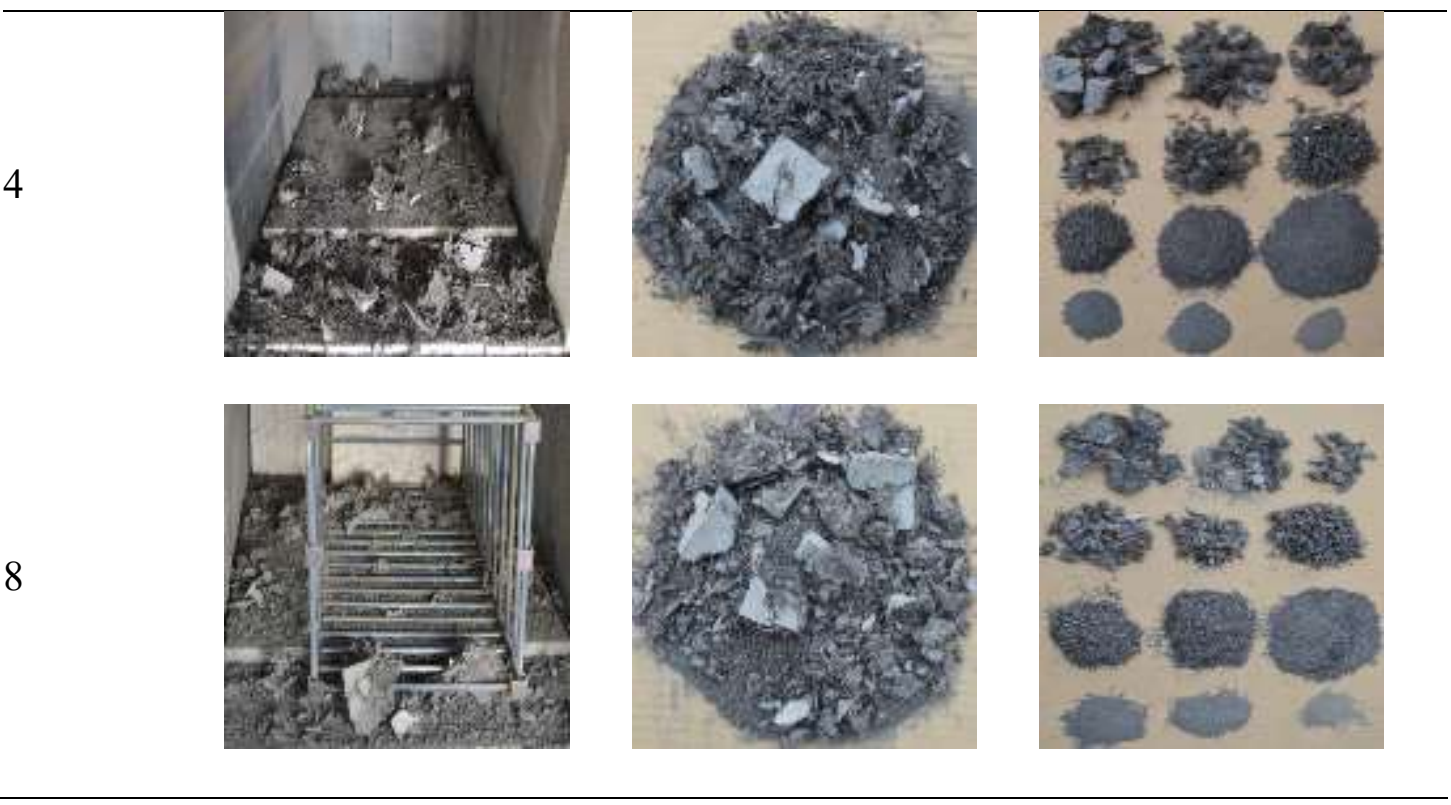

334 In this subsection, the explosive spalling of the mixtures without PP fibres, i.e. Q-0, Q-S

335 and S-0, were compared under the identical target temperature of $400{ }^{\circ} \mathrm{C}$ and heating 336 rate of $4{ }^{\circ} \mathrm{C} / \mathrm{min}$. The details of the explosive spalling are listed in Table 8 and Table 9 337 and the sieving results of debris are shown in Fig. 6. All the mixtures suffered explosive 338 spalling when being heated to the target temperature as shown in Table 8 and broke into 339 pieces as shown in Table 9. Accompanying each explosive spalling, it was observed 340 that some vapour was intensively released. This phenomenon indicated the built-up 341 vapour pressure was an important contribution to the explosive spalling.

343 Compared with the Q-0 concrete without any fibres, the Q-S concrete reinforced with 2 344 vol.\% steel fibres started exploding at a higher temperature. It was because explosive 345 spalling would not happen until the internal vapour pressure was greater than the tensile 346 strength of the concrete which was considerably increased by the addition of steel fibre. 347 The S-0 concrete which had steel slag as fine aggregate had almost the same spalling 
348 starting time but higher starting temperature in comparison with the Q-0 and Q-S

349 concretes which had quartz sand as fine aggregate.

350

351 Table 8

352 Details of explosive spalling of mixtures without PP fibres at heating rate of $4{ }^{\circ} \mathrm{C} / \mathrm{min}$

\begin{tabular}{lccc}
\hline Mixture & Q-0 & Q-S & S-0 \\
\hline Target temperature $\left({ }^{\circ} \mathrm{C}\right)$ & 400 & 400 & 400 \\
Probability (\%) & 100 & 100 & 100 \\
Starting time (min) & 86 & 92 & 92 \\
Ending time (min) & 109 & 113 & 147 \\
Starting temperature $\left({ }^{\mathrm{a}} \mathrm{C}\right)^{\mathrm{b}}$ & 338 & 357 & 385 \\
Ending temperature $\left({ }^{\circ} \mathrm{C}\right)^{\mathrm{b}}$ & 400 & 400 & 400 \\
\hline
\end{tabular}

$353 \quad \overline{\mathrm{a}, \mathrm{b}}$ Same as in Table 6.

354

355 Table 9

356 Explosive spalling of mixtures without PP fibres at heating rate of $4{ }^{\circ} \mathrm{C} / \mathrm{min}$

\begin{tabular}{l} 
Mixture \\
\hline Q-0
\end{tabular}




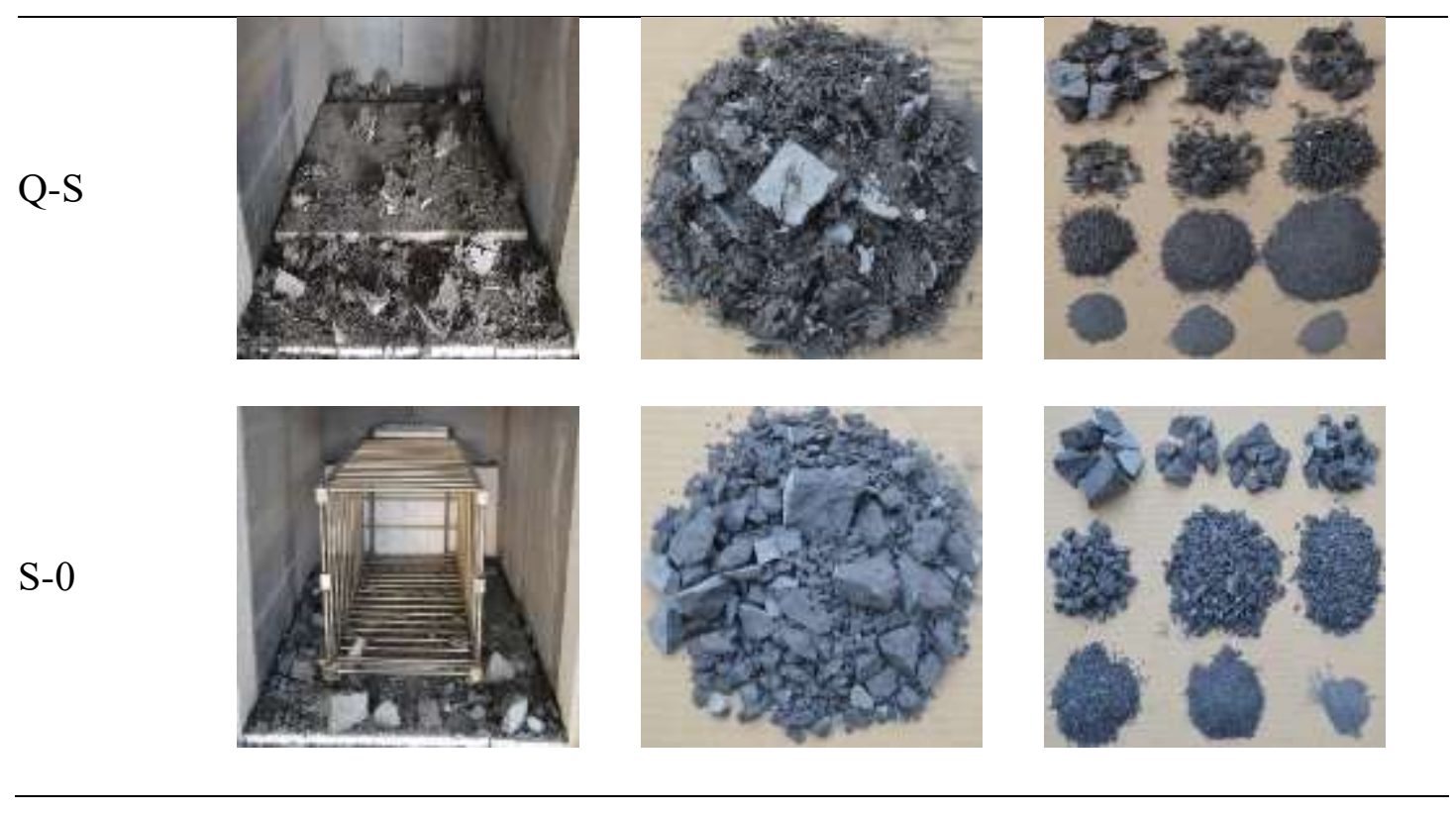

358 Fig. 6 exhibits sieving results of debris of the three mixtures without PP fibres, which

359 reflects effect of steel fibre and difference between the two types of aggregate on 360 explosive spalling. Among the three mixtures, the Q-S concrete had the greatest 361 proportion in both large and small debris sizes as shown in Fig. 6. The steel fibres 362 bridged the gaps when the cracks were growing and thus restrained propagation of the 363 cracks, which helped the Q-S concrete remain more large-size debris than the other two 364 without steel fibres. On the other hand, the constraint effect of the steel fibres caused 365 greater vapour pressure, which resulted in more small-size debris after the specimens 366 exploded. Compared to the Q-0 concrete, the S-0 concrete containing steel slag had a 367 higher percentage of debris with sizes over $4.5 \mathrm{~mm}$. The reason could be the steel slag 368 produced under $1,650{ }^{\circ} \mathrm{C}$ had relatively high thermal stability and similar chemical 369 compositions to the cement, which reduced thermal incompatibility between the fine 370 aggregate and the cement paste. 


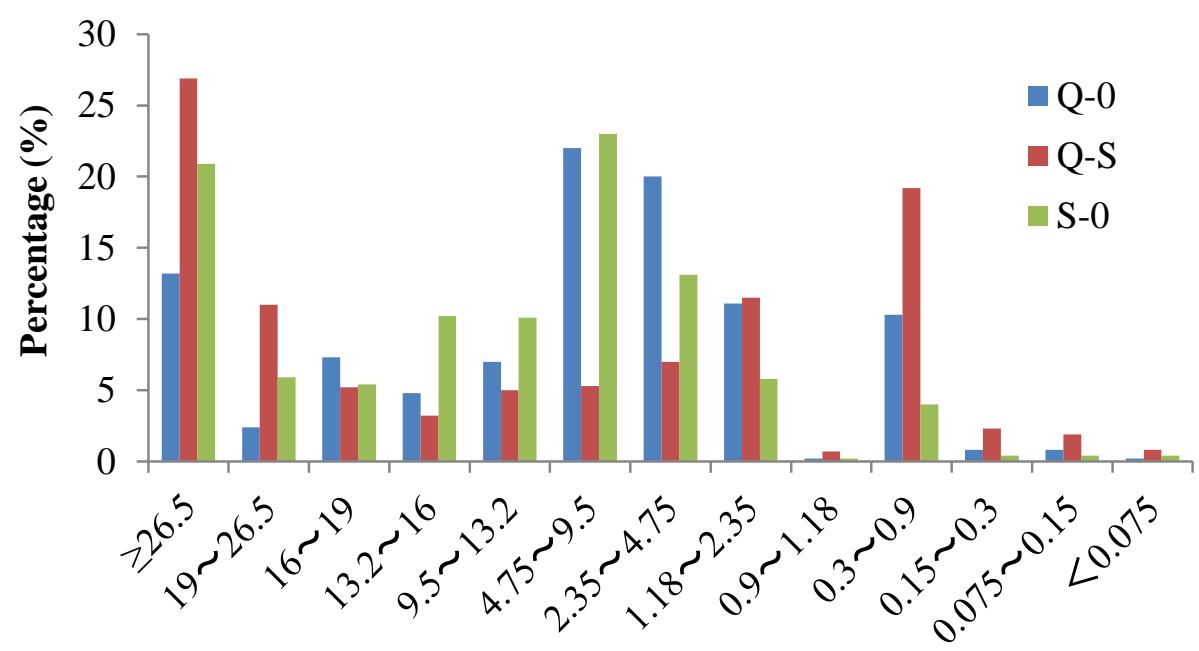

Particle size (mm)

Fig. 6. Sieving results of debris of mixtures without PP fibres.

377 As discussed above, PP fibre, which melts at about $165^{\circ} \mathrm{C}$, helps release vapour 378 pressure and thus reduces the risk of explosive spalling when concrete is exposed to 379 elevated temperatures. In this subsection, three mixtures containing PP fibres, i.e., the 380 Q-P, Q-SP and S-SP concretes, are compared in terms of explosive spalling. The three 381 concretes were heated to five target temperatures, i.e. $200,400,600,800$ and $1,000{ }^{\circ} \mathrm{C}$, 382 with explosive spalling details reported in Table 10. Spalling damage of these 383 specimens is displayed in Table 11, where unheated specimens are also listed in order to 384 make a comparison.

386 Table 10

387 Details of explosive spalling of mixtures with PP fibres under different target 388 temperatures 


\begin{tabular}{|c|c|c|c|c|c|c|}
\hline \multicolumn{4}{|c|}{ Target tempera-Spalling probability $(\%)$} & \multicolumn{3}{|c|}{ Spalling temperature range $\left({ }^{\circ} \mathrm{C}\right)$} \\
\hline ture $\left({ }^{\circ} \mathrm{C}\right)$ & $\overline{\mathrm{Q}-\mathrm{P}}$ & Q-SP & S-SP & $\overline{\mathrm{Q}-\mathrm{P}}$ & Q-SP & S-SP \\
\hline 200 & 0 & 0 & 0 & - & - & - \\
\hline 400 & 0 & 0 & 50 & - & - & $392-400^{a}$ \\
\hline 600 & 75 & 50 & 50 & $404-458$ & $447-464^{\mathrm{a}}$ & $467-503^{\mathrm{a}}$ \\
\hline 800 & 75 & 0 & 50 & $409-472$ & - & $391-440^{a}$ \\
\hline 1,000 & 100 & 50 & 25 & $413-463$ & $437-457^{\mathrm{a}}$ & $464^{\mathrm{a}}$ \\
\hline
\end{tabular}

391 From Table 10 and Table 11, it can be seen all the specimens didn't experience 392 explosive spalling at the target temperature of $200{ }^{\circ} \mathrm{C}$. Under the $400{ }^{\circ} \mathrm{C}$ target 393 temperature, half of the four S-SP specimens suffered slight spalling but the other two 394 remained intact. With target temperature over $600{ }^{\circ} \mathrm{C}$, all the specimens experienced 395 spalling to some degree, which occurred between $391{ }^{\circ} \mathrm{C}$ and $503{ }^{\circ} \mathrm{C}$. However, unlike 396 in the tests of the mixtures without PP fibres, no intensive release of vapour was 397 observed coming with any of the spalling. The spalling could result from thermal stress 398 and incompatibility between the aggregate and the cement paste but not vapour 399 pressure. It can also be seen from Table 10 and Table 11 that the Q-P concrete which 400 had only PP fibres suffered more frequent and severer spalling than the other two 401 reinforced with hybrid fibres. Steel fibre failed to prevent the occurrence of explosion 402 resulting from built-up vapour pressure as discussed in subsection 3.2.2, but it reduced 403 probability and intensity of spalling resulting from thermal stress and incompatibility 404 between the aggregate and the cement paste. When being heated from $20^{\circ} \mathrm{C}$ to $1,000{ }^{\circ} \mathrm{C}$, 405 all the specimens experienced a colour change from grey to grey-white and then amber, 406 as shown in Table 11. 
408 Table 11

409 Explosive spalling of mixtures with PP fibres under different temperatures

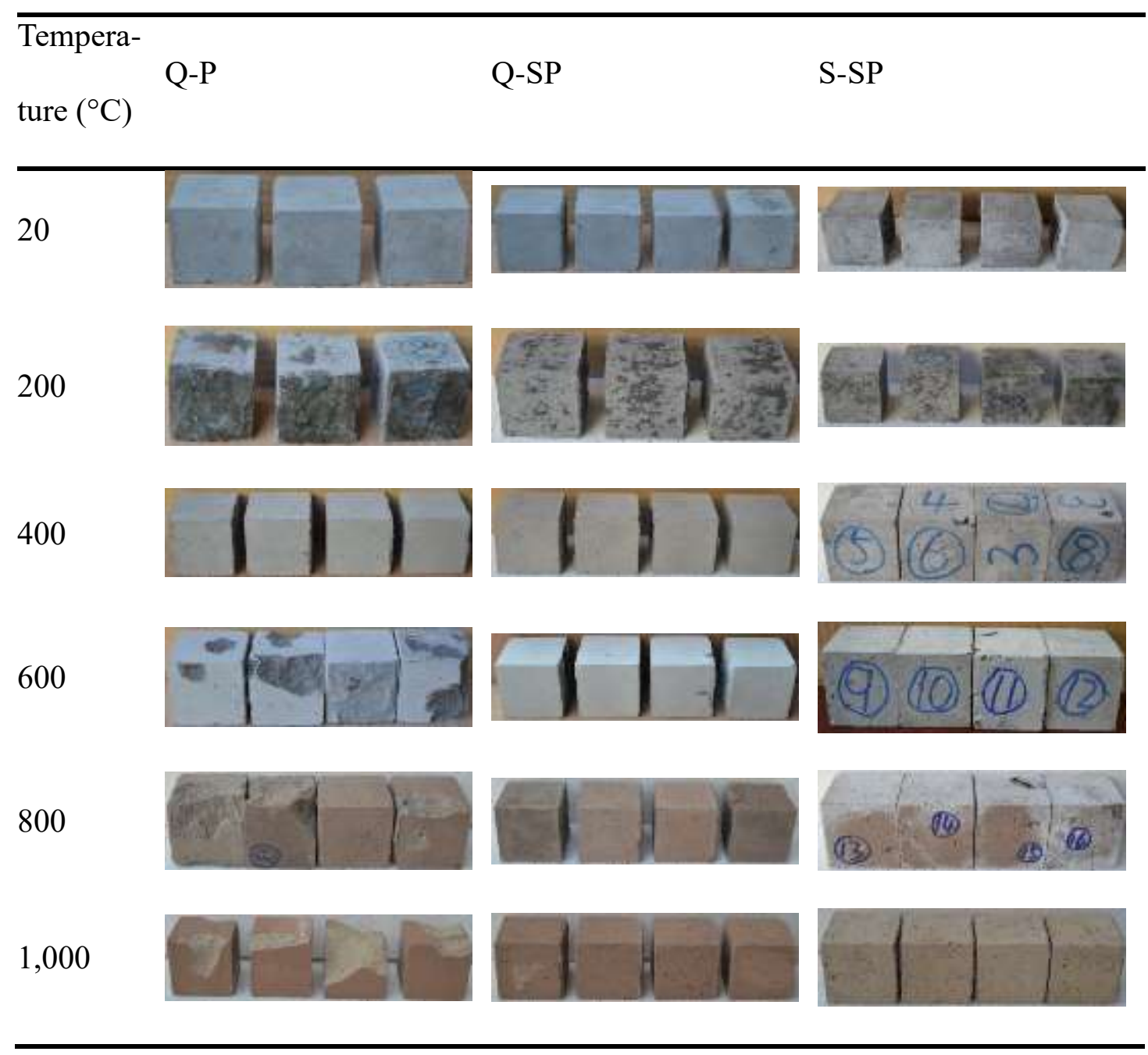

410

411 3.3. Compressive tests

412

413 3.3.1. Specimens without PP fibres

414

415 Because of severe explosive spalling when being heated to $400{ }^{\circ} \mathrm{C}$ and above, the

416 specimens without PP fibres were tested only at room temperature and $200{ }^{\circ} \mathrm{C}$. For the

417 compressive tests, failure forms of the three mixtures, i.e. Q-0, Q-S and S-0, are 
418 displayed in Table 12. Without addition of any fibres, both the Q-0 and S-0 concretes

419 suffered brittle damage and were crushed up under either temperature. By contrast,

420 the Q-S concrete reinforced with steel fibres improved a lot in ductility and remained

421 its integrity under the compressive loading. The UHPC mixtures had highly compact

422 structure, leading to reduced relative stiffness to the steel loading plate. The internal

423 energy of the loading plate building up during the loading procedure was released

424 suddenly when the specimen yielded, which resulted in the crush of the specimens

425 without steel fibres due to inadequate tensile strength.

427 Table 12

428 Failure forms of mixtures with PP fibres under different temperatures

\begin{tabular}{lll}
\hline Tempera- & Q-S & S-0 \\
ture $\left({ }^{\circ} \mathrm{C}\right)$ & Q-0 &
\end{tabular}

20
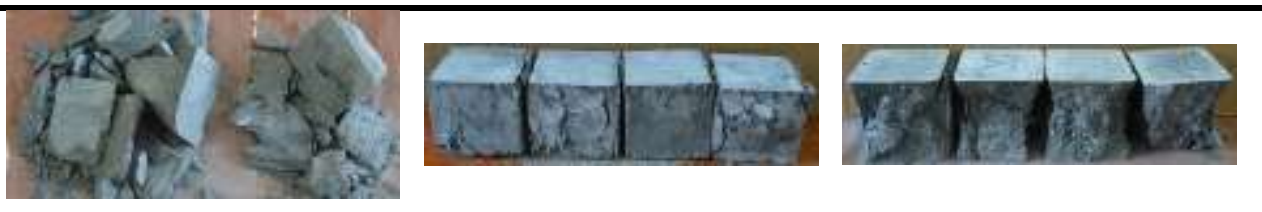

200
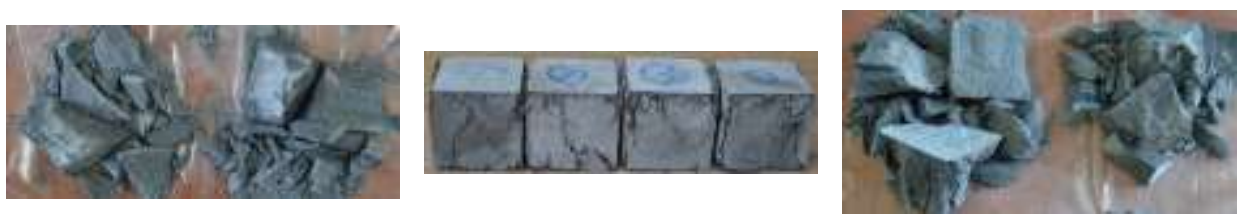

430 Stress-strain curves for the three mixtures under room temperature and $200{ }^{\circ} \mathrm{C}$ are

431 shown in Fig. 7. It can be seen that at $200{ }^{\circ} \mathrm{C}$ all the three mixtures enjoyed an

432 improvement of compressive strength in comparison with at room temperature. The

433 reason could be that high-pressure moisture failing to escape due to the tight structure

434 of the UHPC specimen created an enclosed high-temperature and high-pressure curing

435 environment or "internal autoclaving" [39]. This curing environment greatly boosted 
436 both cement hydration and pozzolanic reactions due to the presence of active $\mathrm{SiO}_{2}$

437 from silica fume and fly ash, generating more C-S-H gel. There the C-S-H gel was 438 transformed into xonotlite and tobermorite, which made the internal structure of the 439 specimen even more compact and thus enhanced its compressive strength. As shown 440 in Table 5, when being heated to $200{ }^{\circ} \mathrm{C}$ the Q- 0 concrete had a $47 \%$ increase of 441 compressive strength, while it was only 6\% for the Q-P concrete in comparison with 442 their respective original room-temperature strength. It was because PP fibre enhanced 443 the room-temperature strength of the Q-P concrete but its melting at $165^{\circ} \mathrm{C}$ made this 444 enhancement invalid. On the other hand, the melting of PP fibres left pores in the 445 concrete, which resulted in more cracks when the concrete was under pressure and 446 reduced moisture pressure due to the release of vapour. These weakened the boost 447 effect resulting from the high-temperature and high-pressure curing environment. From 448 Table 5, it can also be seen the Q-S concrete had an unimpressive 9\% improvement of 449 compressive strength compared to $47 \%$ for the Q-0 concrete and $112 \%$ for the S-0 450 concrete when exposed to $200{ }^{\circ} \mathrm{C}$. The reason is the Q-S concrete reinforced with steel 451 fibres had comparatively high compressive strength at room temperature. Fig. 7 also 452 shows the Q-S concrete had much higher ductility and toughness than the other 453 concretes under either temperature. 


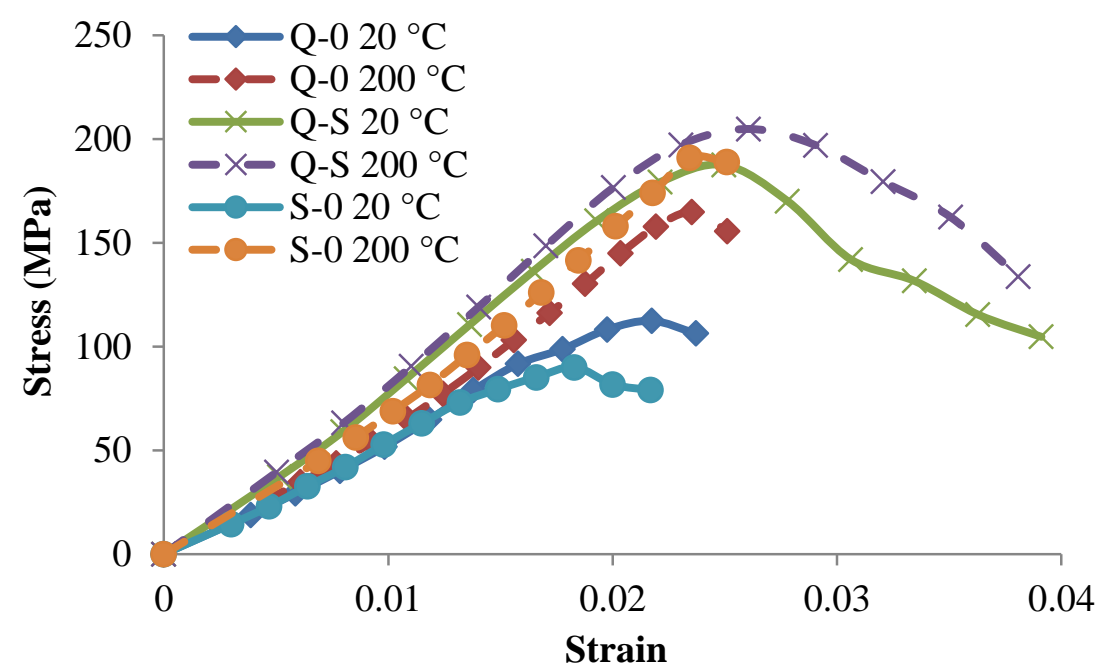

Fig. 7. Stress versus strain curves.

\subsubsection{Specimens with PP fibres}

460 Table 13 shows the failure forms of the three mixtures containing PP fibres exposed to 461 temperatures ranging from $20{ }^{\circ} \mathrm{C}$ to $1,000{ }^{\circ} \mathrm{C}$. As can be seen, the Q-P concrete 462 suffered a ductile damage at room temperature, but under temperatures 200,400 and $463600{ }^{\circ} \mathrm{C}$ its damage was in a brittle manner. It was because the PP fibres improved the 464 ductility of the Q-P concrete under room temperature. However, when it was heated to $465200{ }^{\circ} \mathrm{C}$ and above, the melted PP fibres resulted in deterioration of ductility of the 466 concrete. Under $800{ }^{\circ} \mathrm{C}$ and $1,000{ }^{\circ} \mathrm{C}$, the Q-P concrete exhibited a ductile failure mode 467 again. This was because the concrete had been loosened and softened. Rashad et al. [39] 468 pointed out coarsening of pore-structure can happen when cement paste is heated to $469400{ }^{\circ} \mathrm{C}$ and above and $\mathrm{C}-\mathrm{S}-\mathrm{H}$ can be dramatically decomposed at $600{ }^{\circ} \mathrm{C}$ and above,

470 which may lead to concrete loosening and softening and cohesiveness deterioration of 471 cement paste. Due to the cohesiveness deterioration of the cement paste, a double 472 pyramid was formed during the compressive test on the Q-P concrete subjected to $473800{ }^{\circ} \mathrm{C}$ and $1,000{ }^{\circ} \mathrm{C}$, as shown in Table 13 . Compared to the Q-P concrete, the Q-SP 
474 and S-SP concretes experienced ductile damage forms under compression throughout

475 all the target temperatures from $20^{\circ} \mathrm{C}$ to $1,000{ }^{\circ} \mathrm{C}$. Not only did the addition of hybrid

476 fibres restrain occurrence of severe explosive spalling, but also it greatly improved the

477 ductility of the concrete exposed to high temperatures. Under $1,000{ }^{\circ} \mathrm{C}$, however, the

478 Q-SP and S-SP concretes had the similar failure form to the Q-P concrete. This could be

479 attributed to the loss of strength of steel fibres under high temperatures. According to

480 the European standard [40], under $800^{\circ} \mathrm{C}$ and $1,000{ }^{\circ} \mathrm{C}$ steel retains only $11 \%$ and $4 \%$

481 of its yield strength respectively.

482

483 Table 13

484 Compressive failure forms of mixtures with PP fibres under different temperatures

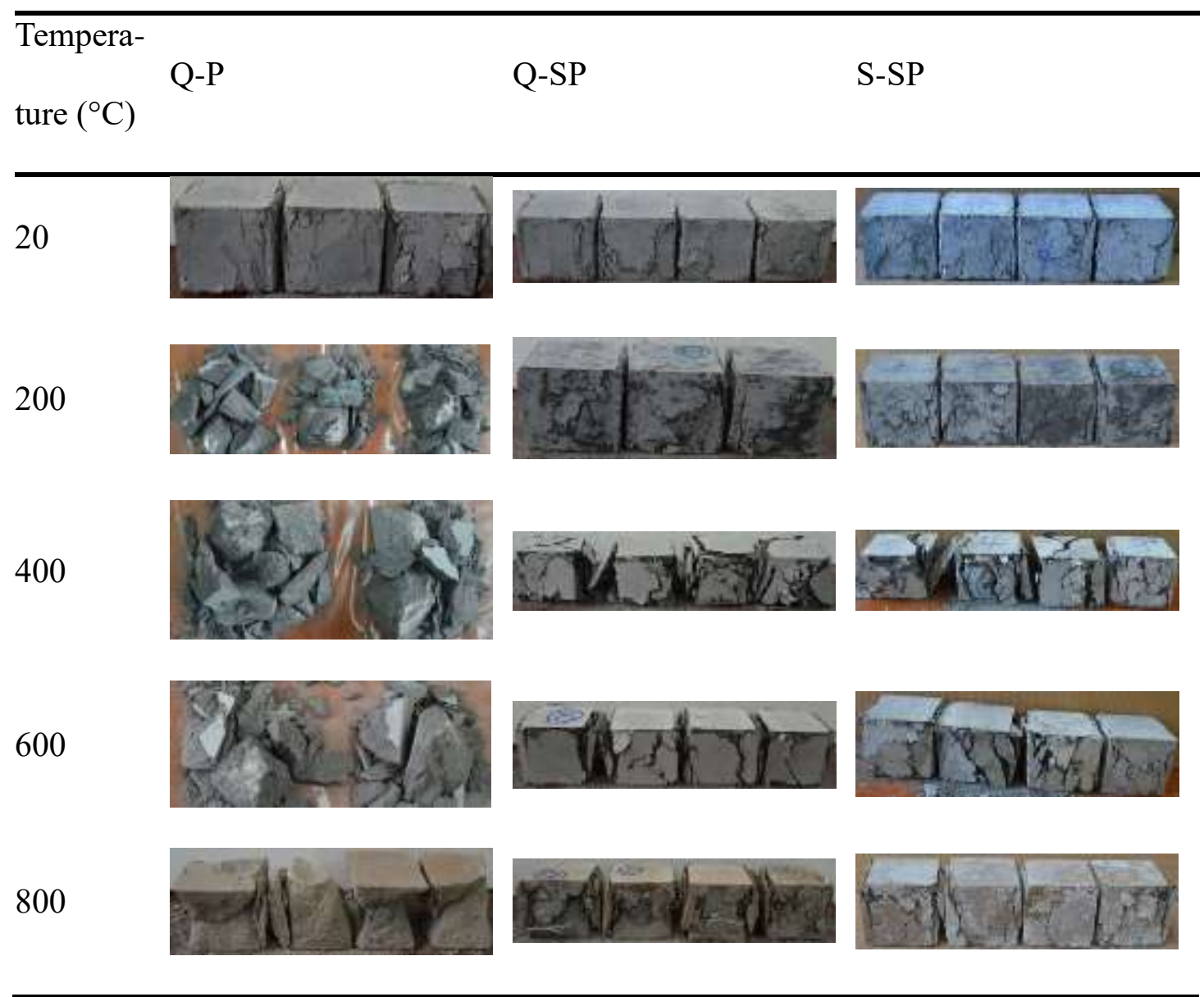


The relationships between compressive strength and temperature for the three $400{ }^{\circ} \mathrm{C}$, all the three concretes made an improvement in compressive strength. From room temperature to $200{ }^{\circ} \mathrm{C}$, the enhancement mechanism is the same as discussed in

490 subsection 3.3.1. From $200{ }^{\circ} \mathrm{C}$ to $400{ }^{\circ} \mathrm{C}$, more $\mathrm{C}-\mathrm{S}-\mathrm{H}$ gel was produced and 491 transformed into xonotlite and tobermorite as pozzolanic reactions continued under 492 the high-temperature and high-pressure environment. In addition, evaporation of 493 bound water made the cement paste more compact and harder. Also during this stage, 494 PP fibres melted completely, greatly relieving vapour pressure. All these contributed 495 to an enhancement of compressive strength of the three concretes.

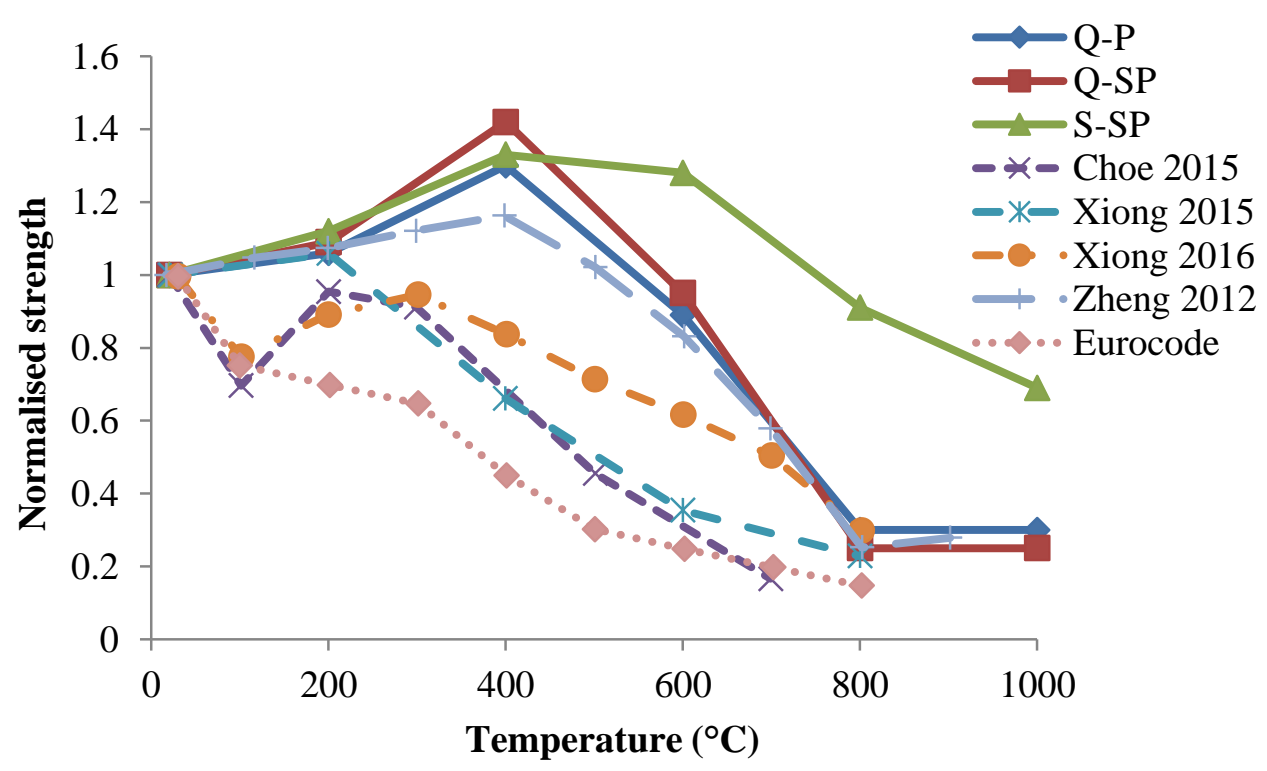


501 can be seen from Fig. 8, the strength loss of the Q-SP concrete was a little steeper than 502 that of the Q-P concrete, while the S-SP concrete had a much slower deterioration of 503 strength than the other two. During this stage, decomposition of the $\mathrm{CH}$ occurred 504 between approximately $430{ }^{\circ} \mathrm{C}$ and $600{ }^{\circ} \mathrm{C}$, while for the C-S-H it started at around $505560{ }^{\circ} \mathrm{C}$ and then became significant above $600{ }^{\circ} \mathrm{C}$ [39]. A large amount of C-S-H was 506 transformed into $\mathrm{C}_{3} \mathrm{~S}$ and $\beta-\mathrm{C}_{2} \mathrm{~S}$ and $\alpha-\mathrm{SiO}_{2}$ was transformed into $\beta-\mathrm{SiO}_{2}$, which 507 resulted in increased porosity in the paste [41]. At $800{ }^{\circ} \mathrm{C}$, the C-S-H was completely 508 decomposed and the $\mathrm{CaCO}_{3}$ started to decompose, contributing to decreased 509 compactness of the internal structure and a lot of small cracks on the surfaces of the 510 specimen. Also, at this stage, the mismatching volume expansion between the cement 511 paste and the aggregate played a significant role that worsened the mechanical 512 performance of the concrete $[13,18]$.

514 From $800{ }^{\circ} \mathrm{C}$ to $1,000{ }^{\circ} \mathrm{C}$, the strength of the Q-P and Q-SP concretes remained almost

515 the same but that of the S-SP concrete kept falling. However, the S-SP concrete 516 retained a relatively high residual strength of $112.8 \mathrm{MPa}$ or normalised residual 517 strength of $69 \%$ after being exposed to $1,000{ }^{\circ} \mathrm{C}$, while that for the Q-P and Q-SP 518 concretes was only $40 \mathrm{MPa}$ or below $30 \%$.

520 Fig. 8 also shows the results of UHPCs from other researches $[4,7,8,25]$ and high 521 strength concrete according to the European standard EN 1992-1-2 [37]. It can be 522 seen over $600{ }^{\circ} \mathrm{C}$ the S-SP concrete retained markedly higher normalised strength than 523 the other concretes. The main reason could be, on one hand, adding steel slag to the 524 mixture reduced the amount of $\mathrm{CH}$ formed during the hydration, which increased the 525 fire resistance of the mixture exposed to elevated temperatures [42, 43]. On the other 
hand, steel slag usually has rough surfaces and thus improves properties of interfacial transition zone (ITZ), which could be critical for concrete under high temperatures. Research conducted by Jia [44] revealed NSC exposed to high temperatures above $300{ }^{\circ} \mathrm{C}$ exhibited different damage modes under compressive loading. The damage occurred along the ITZ or within the paste other than running through the aggregate

531 which was the case for unheated concretes, indicating high temperature could severely degrade properties of ITZ. Ducman and Mladenovič [13] and Netinger et al. [18] suggested a major factor contributing to strength loss of concrete using steel slag as aggregate is the expansion of steel slag in contrast to the shrinkage of cement paste after exposed to high temperatures. However, in this study steel slag was used as fine aggregate and most of it had a size smaller than $2.5 \mathrm{~mm}$, which could mitigate the negative effect of volume mismatching between the steel slag and the cement paste.

538 Besides, as discussed in subsection 3.2, steel slag had excellent thermal stability and similar chemical compositions to cement, which reduced thermal incompatibility 540 between the fine aggregate and the cement paste and could improve residual 541 properties. From Fig. 8, it can also be seen the S-SP concrete was the only one that had 542 its strength under $600{ }^{\circ} \mathrm{C}$ higher than its room-temperature strength.

544 Fig. 9 shows the SEM analysis of the S-SP concrete after exposure to temperatures from $54520{ }^{\circ} \mathrm{C}$ to $800{ }^{\circ} \mathrm{C}$, using a JEOL JSM-7800F SEM. For the S-SP specimen never 546 subjected to an elevated temperature, it had continuous and compact C-S-H phase and 547 scattered $\mathrm{CH}$ crystals. After exposed to $200{ }^{\circ} \mathrm{C}$, the $\mathrm{C}-\mathrm{S}-\mathrm{H}$ phase in the concrete 548 remained continuous and became more compact while the $\mathrm{CH}$ crystals became fewer 549 and smaller. However, due to melting of PP fibre and cracking resulting from vapour 550 pressure, the matrix presented a rougher surface. After subjected to $400{ }^{\circ} \mathrm{C}$, the $\mathrm{C}-\mathrm{S}-\mathrm{H}$ 
551 phase had even more compact structure and better integrity while the $\mathrm{CH}$ phase

552 continued to reduce in quantity and size. Suffering $600{ }^{\circ} \mathrm{C}$, the C-S-H phase lost some

553 continuity and integrity due to decomposition and became less compact. At the same

554 time, the $\mathrm{CH}$ phase completely decomposed. At $800^{\circ} \mathrm{C}$, the $\mathrm{C}-\mathrm{S}-\mathrm{H}$ phase did not exist

555 any longer and the matrix was honeycombed, resulting in greatly worsened concrete

556 performance.

557

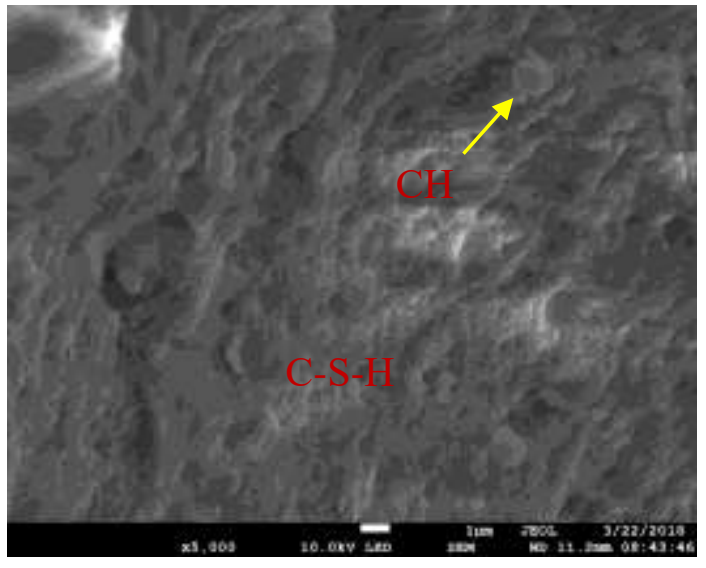

(a) $20{ }^{\circ} \mathrm{C}$

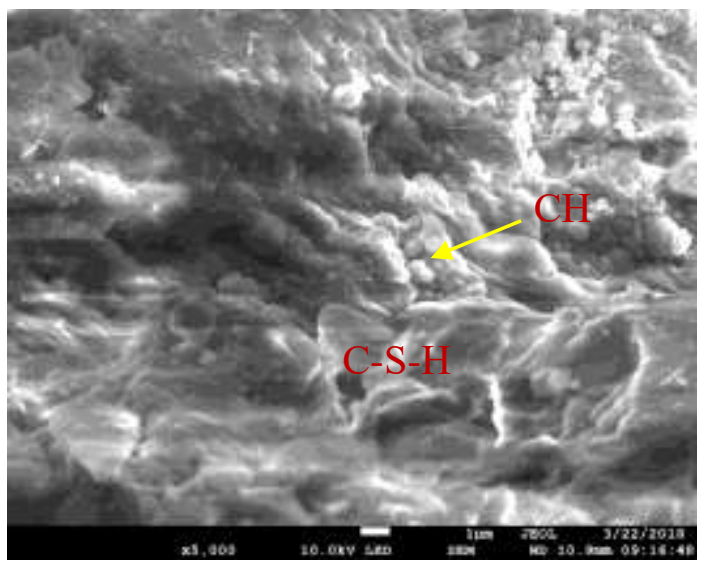

(c) $400{ }^{\circ} \mathrm{C}$

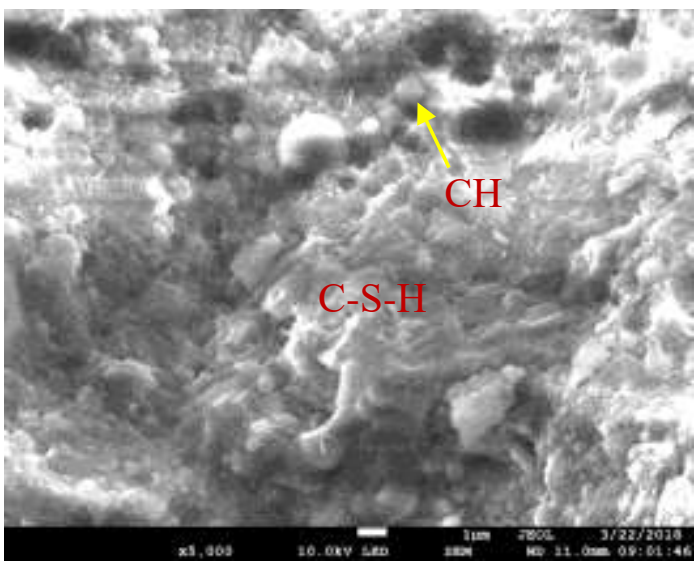

(b) $200^{\circ} \mathrm{C}$

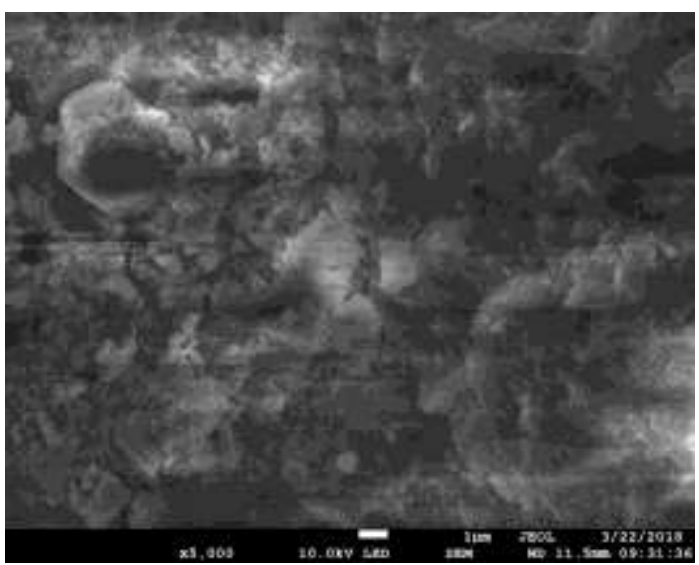

(d) $600{ }^{\circ} \mathrm{C}$ 


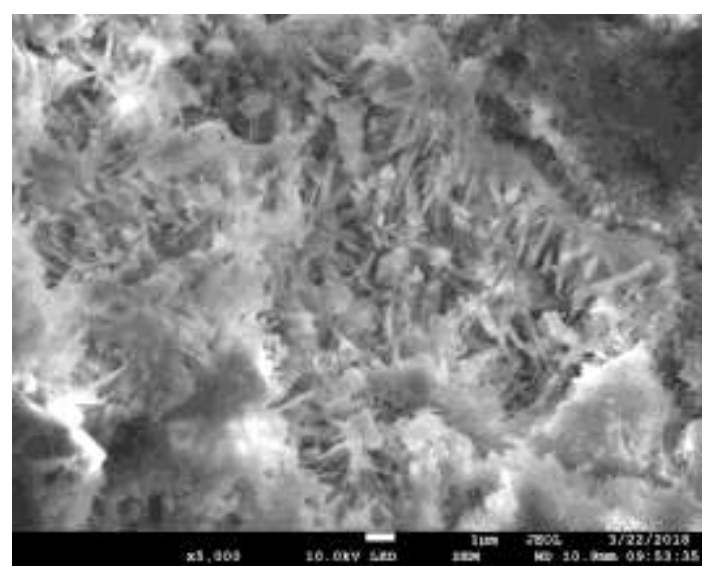

(e) $800{ }^{\circ} \mathrm{C}$

Fig. 9. SEM analysis of S-SP concrete after exposure to different temperatures.

560 The stress-strain curves of the three concretes under different temperatures from $20{ }^{\circ} \mathrm{C}$

561 to $1,000{ }^{\circ} \mathrm{C}$ are depicted in Fig. 10, Fig. 11 and Fig. 12, respectively. It can be seen the 562 stress-strain curves of the Q-P and the Q-SP concretes had the similar varying pattern 563 under different temperatures. For example, both the concretes suffered a significant 564 drop in strength and modulus elasticity when being heated to $600{ }^{\circ} \mathrm{C}$ and above and had 565 a flattened stress-strain curve under $800{ }^{\circ} \mathrm{C}$ and $1,000{ }^{\circ} \mathrm{C}$. As discussed above, the 566 concretes were loosened and softened when being heated to higher than $800{ }^{\circ} \mathrm{C}$. 567 Nevertheless, due to the addition of steel fibres, the Q-SP concrete exhibited greater 568 ductility and toughness than the Q-P concrete under whatever temperatures. From Fig. 56912 it can be seen even under $600^{\circ} \mathrm{C}$ the S-SP concrete had strength much higher than its 570 room-temperature strength and relatively high modulus elasticity. Under higher 571 temperatures up to $1,000{ }^{\circ} \mathrm{C}$, the $\mathrm{S}-\mathrm{SP}$ concrete retained relatively high residual 572 strength and modulus elasticity in comparison with the Q-P and the Q-SP concretes. 


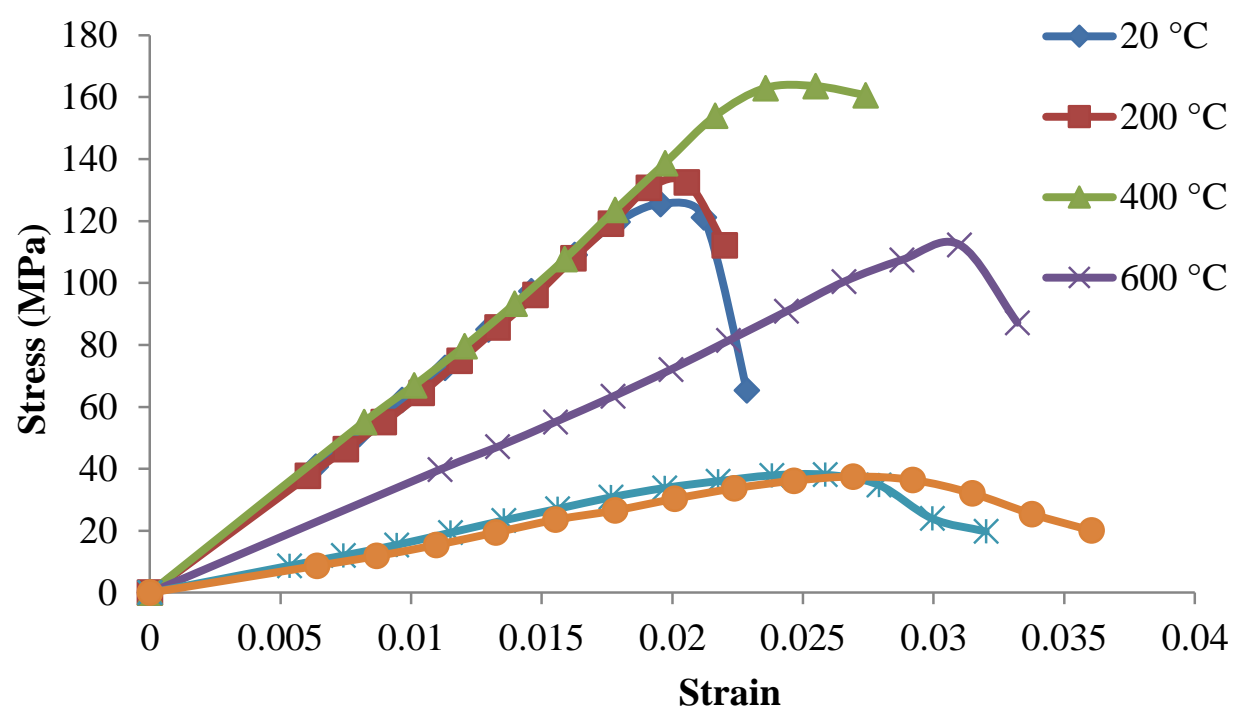

Fig. 10. Stress versus strain curves of Q-P concrete.

576

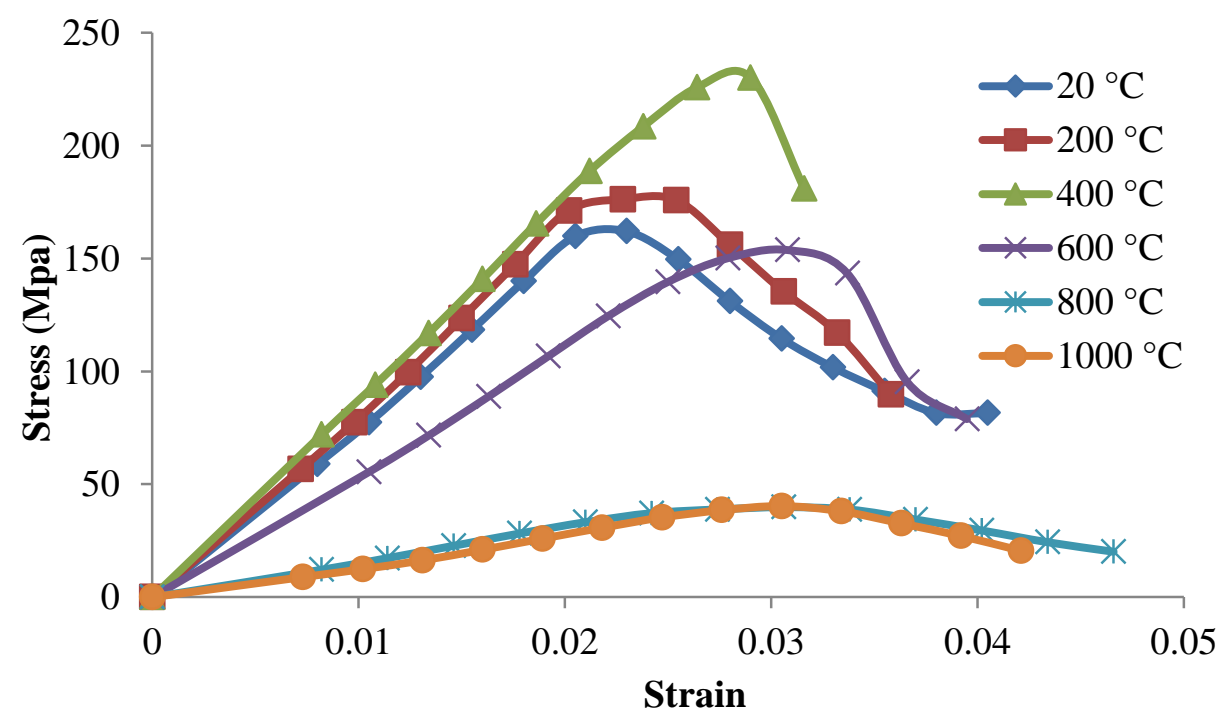

Fig. 11. Stress versus strain curves of Q-SP concrete. 


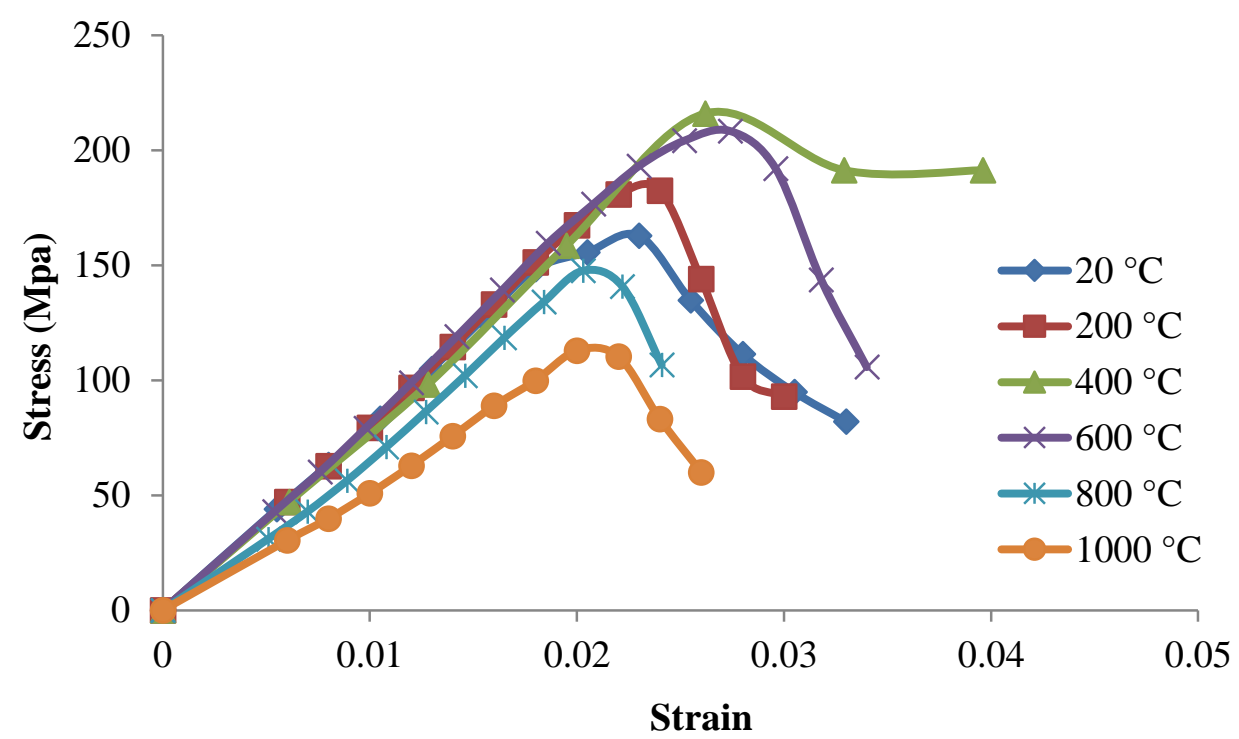

Fig. 12. Stress versus strain curves of S-SP concrete.

582 Fig. 13 shows relationships between normalised modulus of elasticity and temperature

583 of the three UHPC mixtures as well as light weight concrete from the European 584 standard EN 1992-1-2 [37]. It should be noted modulus of elasticity here was 585 calculated as the slope between two points on the ascending portion of stress-strain 586 curves corresponding to $60 \%$ and $40 \%$ of peak stress respectively, which was also 587 adopted by $\mathrm{Su}$ et al. [45]. The curves for the three UHPCs in Fig. 13 has a similar 588 pattern to those in Fig. 8, though increase of modulus of elasticity was much less 589 impressive than that of strength from $20{ }^{\circ} \mathrm{C}$ to $600{ }^{\circ} \mathrm{C}$. It can also be seen the 590 degradation of modulus of elasticity of concrete specified in the European standard 591 EN 1992-1-2 [37] is much severer than the three UHPCs under whatever elevated 592 temperatures. 


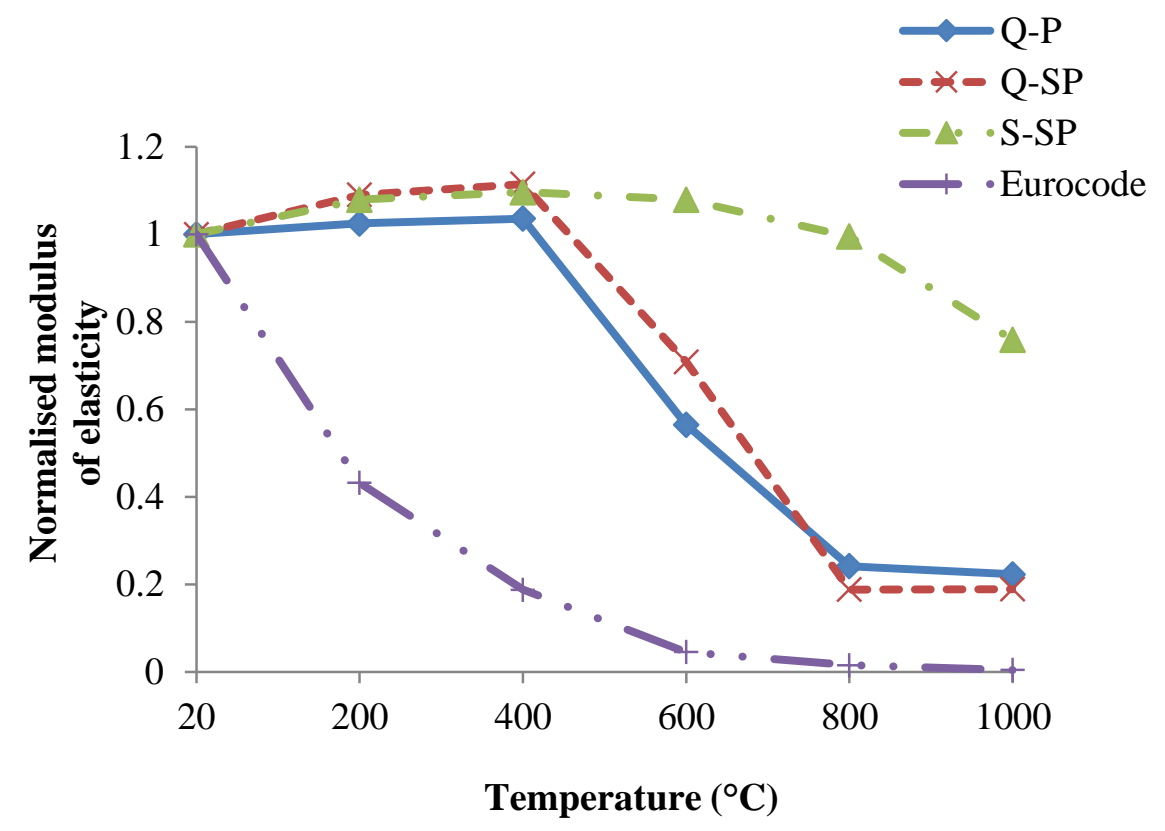

Fig. 13. Normalised modulus of elasticity versus temperature.

\section{Conclusions}

599 To develop a UHPC with excellent fire resistance, a total of six UHPC mixtures were

600 designed using quartz sand or steel slag as fine aggregate, with or without steel fibre,

601 PP fibre or hybrid fibre. Special attention was paid to explosive spalling of UHPCs

602 subjected to elevated temperatures since UHPCs are usually of compact structure and 603 thus vulnerable to explosive spalling. Besides, residual compressive strengths and 604 stress-strain relationships of the UHPC mixtures are discussed after they were heated 605 to elevated temperatures up to $1,000{ }^{\circ} \mathrm{C}$. The following conclusions could be drawn 606 from the test results and the above analysis:

607 1. Most mass loss of the mixtures with PP fibre happened between $200{ }^{\circ} \mathrm{C}$ and $400{ }^{\circ} \mathrm{C}$ 608 due to water evaporation and PP volatilisation.

609 2. Heating rate had little effect on explosive spalling occurrence of the Q-S mixture, 610 which had very dense matrix without PP fibres. However, higher heating rate could 
611 result in more intense explosive spalling.

612 3. Vapour pressure was a significant contribution to explosive spalling. PP fibre was an

613 effective additive to control explosive spalling, though failed to eliminate it 614 completely. Steel fibre could reduce the probability and intensity of spalling 615 resulting from thermal stress and incompatibility between aggregate and cement 616 paste.

617 4. A UHPC mixture with excellent fire-resistance properties was successfully 618 developed. After being exposed to $1,000{ }^{\circ} \mathrm{C}$, it retained $69 \%$ of its original 619 compressive strength, much higher than the existing concretes. Reinforced with 620 hybrid fibre, this concrete also greatly decreased the occurrence of explosive $621 \quad$ spalling.

622 5. Addition of steel slag to UHPC mixtures reduced amount of $\mathrm{CH}$ formed during 623 hydration. With rough surface, steel slag could improve ITZ properties of UHPCs 624 exposed to elevated temperatures. Having high thermal stability and similar 625 chemical compositions to cement, steel slag as fine aggregate also relieved thermal 626 incompatibility between aggregate and cement paste. These features of steel slag 627 may significantly improve residual properties of UHPCs using steel slag as fine 628 aggregate.

630 Acknowledgement

631

632 The authors gratefully acknowledge the financial support of the Australian Research

633 Council grant DP160104661, the National Basic Research Programme 2015CB058002 634 and the Australian Government Research Training Program Scholarship. 
638 [1] Y. Su, J. Li, C. Wu, P. Wu, Z.-X. Li, Influences of nano-particles on dynamic 639 strength of ultra-high performance concrete, Composites Part B: Engineering 91 (2016) 640 595-609.

641 [2] Y. Su, C. Wu, J. Li, Z.-X. Li, W. Li, Development of novel ultra-high performance 642 concrete: From material to structure, Construction and Building Materials 135 (2017) 643 517-528.

644 [3] Y.N. Chan, X. Luo, W. Sun, Compressive strength and pore structure of 645 high-performance concrete after exposure to high temperature up to $800^{\circ} \mathrm{C}$, Cement 646 and Concrete Research 30 (2000) 247-251.

647 [4] G. Choe, G. Kim, N. Gucunski, S. Lee, Evaluation of the mechanical properties of $648200 \mathrm{MPa}$ ultra-high-strength concrete at elevated temperatures and residual strength of 649 column, Construction and Building Materials 86 (2015) 159-168.

650 [5] Y.W. Lee, G.Y. Kim, N. Gucunski, G.C. Choe, M.H. Yoon, Thermal strain behavior 651 and strength degradation of ultra-high-strength-concrete, Materials and Structures 49(8) 652 (2015) 3411-3421.

653 [6] A.Q. Sobia, M.S. Hamidah, I. Azmi, S.F.A. Rafeeqi, Elevated temperature 654 resistance of ultra-high-performance fibre-reinforced cementitious composites, 655 Magazine of Concrete Research 67(17) (2015) 923-937.

656 [7] M. Xiong, J.Y. Richard Liew, Spalling behavior and residual resistance of fibre reinforced Ultra-High performance concrete after exposure to high temperatures, Materiales de Construcción 65(320) (2015) e071.

[8] M.-X. Xiong, J.Y.R. Liew, Mechanical behaviour of ultra-high strength concrete at elevated temperatures and fire resistance of ultra-high strength concrete filled steel tubes, Materials \& Design 104 (2016) 414-427.

[9] C. Kahanji, F. Ali, A. Nadjai, Experimental study of ultra-high performance fibre reinforced concrete under ISO 834 fire, Structures in Fire (Proceedings of the Ninth International Conference), 2016, pp. 165-173.

[10] C. Kahanji, F. Ali, A. Nadjai, Explosive spalling of ultra-high performance fibre reinforced concrete beams under fire, Journal of Structural Fire Engineering 7(4) (2016) 328-348.

[11] W.M. Lin, T.D. Lin, L.J. Powers-Couche, Microstructures of fire-damaged concrete, ACI Materials Journal 93(3) (1996) 199-205.

[12] A.H. Akca, N. Özyurt Zihnioğlu, High performance concrete under elevated temperatures, Construction and Building Materials 44 (2013) 317-328.

[13] V. Ducman, A. Mladenovič, The potential use of steel slag in refractory concrete, Materials Characterization 62(7) (2011) 716-723.

[14] X. Guo, H. Shi, K. Wu, Effects of steel slag powder on workability and durability of concrete, Journal of Wuhan University of Technology-Mater. Sci. Ed. 29(4) (2014) 733-739.

[15] I. Netinger, D. Bjegović, G. Vrhovac, Utilisation of steel slag as an aggregate in concrete, Materials and Structures 44(9) (2011) 1565-1575.

[16] H. Qasrawi, F. Shalabi, I. Asi, Use of low CaO unprocessed steel slag in concrete as fine aggregate, Construction and Building Materials 23(2) (2009) 1118-1125.

[17] İ. Yüksel, R. Siddique, Ö. Özkan, Influence of high temperature on the properties of concretes made with industrial by-products as fine aggregate replacement, Construction and Building Materials 25(2) (2011) 967-972. 

properties of steel slag aggregate concrete, Fire Safety Journal 59 (2013) 1-7. [19] Y. Su, J. Li, C. Wu, P. Wu, Z.-X. Li, Effects of steel fibres on dynamic strength of UHPC, Construction and Building Materials 114 (2016) 708-718. concrete incorporating coal bottom ash and slag powder, Construction and Building Materials 131 (2017) 459-466.

691 [21] P.S. Ambily, C. Umarani, K. Ravisankar, P.R. Prem, B.H. Bharatkumar, N.R. Iyer, 692 Studies on ultra high performance concrete incorporating copper slag as fine aggregate,

Construction and Building Materials 77 (2015) 233-240.

[22] Y. Biskri, D. Achoura, N. Chelghoum, M. Mouret, Mechanical and durability characteristics of High Performance Concrete containing steel slag and crystalized slag as aggregates, Construction and Building Materials 150 (2017) 167-178.

[23] K.S. Al-Jabri, A.H. Al-Saidy, R. Taha, Effect of copper slag as a fine aggregate on the properties of cement mortars and concrete, Construction and Building Materials 25(2) (2011) 933-938.

[24] I. Netinger, M.J.R. \&, D. Bjegović, A. Mladenovič, Concrete containing steel slag aggregate: Performance after high temperature exposure, in: A.e.a. (eds) (Ed.) Concrete Repair, Rehabilitation and Retrofi tting III, Taylor \& Francis Group, London, 2012. [25] W. Zheng, H. Li, Y. Wang, Compressive behaviour of hybrid fiber-reinforced reactive powder concrete after high temperature, Materials \& Design 41 (2012) 403-409.

[26] B. Nagy, D. Szagri, Hygrothermal Properties of Steel Fiber Reinforced Concretes, Applied Mechanics and Materials 824 (2016) 579-588.

[27] G.-F. Peng, W.-W. Yang, J. Zhao, Y.-F. Liu, S.-H. Bian, L.-H. Zhao, Explosive spalling and residual mechanical properties of fiber-toughened high-performance concrete subjected to high temperatures, Cement and Concrete Research 36(4) (2006) $723-727$.

[28] I. Hager, Behaviour of cement concrete at high temperature, Bulletin of the Polish Academy of Sciences: Technical Sciences 61(1) (2013) 145-154.

[29] G. Debicki, R. Haniche, F. Delhomme, An experimental method for assessing the spalling sensitivity of concrete mixture submitted to high temperature, Cement and Concrete Composites 34(8) (2012) 958-963.

[30] F. Aslani, B. Samali, High Strength Polypropylene Fibre Reinforcement Concrete at High Temperature, Fire Technology 50(5) (2013) 1229-1247.

[31] D.C. Okpala, Pore structure of hardened cement paste and mortar, The InternationaI Journat of Cement Composite\$ and Lightweight Concrete 11(4) (1989) 245-254.

[32] C. Gallé, Effect of drying on cement-based materials pore structure as identified by mercury intrusion porosimetry: A comparative study between oven-, vacuum-, and freeze-drying, Cement and Concrete Research 31 (2001) 1467-1477.

[33] ISO 834-1-1999 (E), Fire-resistance tests - Elements of building construction Part 1: General requirements, International Organization for Standardization, Geveve, 1999.

[34] W. Khaliq, V. Kodur, Thermal and mechanical properties of fiber reinforced high performance self-consolidating concrete at elevated temperatures, Cement and Concrete Research 41(11) (2011) 1112-1122.

[35] ASTM Standard E831-14, Standard test method for linear thermal expansion of solid materials by thermomechanical analysis, ASTM International, West Conshohocken, PA, 2014. 
[36] L. Chen, Q. Fang, X. Jiang, Z. Ruan, J. Hong, Combined effects of high

735 temperature and high strain rate on normal weight concrete, International Journal of 736 Impact Engineering 86 (2015) 40-56.

737 [37] Eurocode, European Committee for Standardization (CEN), EN 1992-1-2 738 Eurocode 2: Design of Concrete Structures, Brussels, 2004.

739 [38] Y. Tsuchiya, K. Sumi, Thermal decomposition products of polypropylene, Journal 740 of Polymer Science: Part A-1 7 (1969) 1599-1607.

741 [39] A.M. Rashad, Y. Bai, P.A.M. Basheer, N.C. Collier, N.B. Milestone, Chemical and 742 mechanical stability of sodium sulfate activated slag after exposure to elevated 743 temperature, Cement and Concrete Research 42(2) (2012) 333-343.

744 [40] Eurocode, European Committee for Standardization (CEN), EN 1993-1-2 745 Eurocode 3: Design of steel structures, Brussels, 2005.

746 [41] H. Li, Y. Wang, H. Xie, W. Zheng, Microstructure analysis of reactive powder 747 concrete after exposed to high temperature (in Chinese), J. Huazhong Univ. of Sci. \& 748 Tech. (Natural Science Edition) 40(5) (2012) 71-75.

749 [42] G.A. Khoury, B.N. Grainger, P.J.E. Sullivan, Transient thermal strain of concrete: 750 literature review, conditions within specimen and behaviour of individual constituent, 751 Magazine of Concrete Research 37(132) (1985) 131-144.

752 [43] A. Mendes, J. Sanjayan, F. Collins, Phase transformations and mechanical strength 753 of OPC/Slag pastes submitted to high temperatures, Materials and Structures 41(2) 754 (2007) 345-350.

755 [44] B. Jia, Static and Dynamic Mechanical Behavior of Concrete at Elevated 756 Temperature (in Chinese), College of Civil Engineering of Chongqing University, 2011, 757 p. 146.

758 [45] H.Y. Su, J.Y. Xu, W.B. Ren, Experimental study on the dynamic compressive 759 mechanical properties of concrete at elevated temperature, Materials \& Design 56 760 (2014) 579-588. 